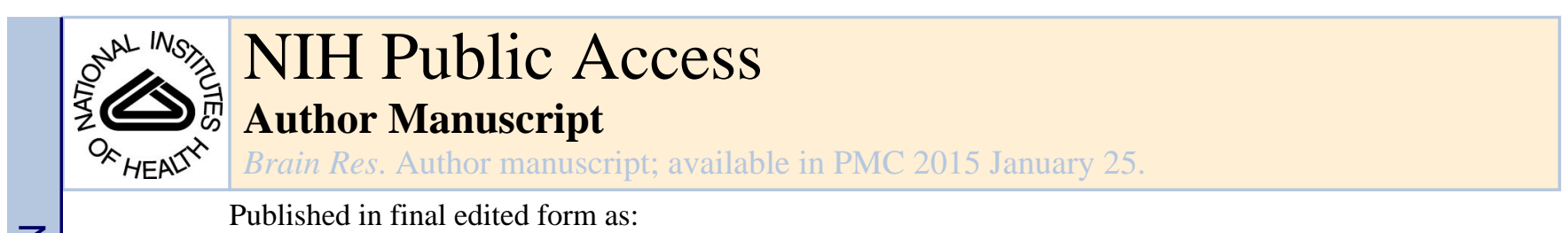

Published in final edited form as:

Brain Res. 2014 September 11; 1580: 199-218. doi:10.1016/j.brainres.2014.01.021.

\title{
Oxytocin and vasopressin systems in genetic syndromes and neurodevelopmental disorders
}

\author{
S.M. Francis ${ }^{a}$, A. Sagarb, T. Levin-Decanini ${ }^{\mathrm{a}}$, W. Liu ${ }^{\mathrm{c}}$, C.S. Carter ${ }^{\mathrm{d}}$, and S. Jacob ${ }^{\mathrm{a},{ }^{\star}}$ \\ aUniversity of Minnesota, Department of Psychiatry, Minneapolis, MN, USA \\ bUniversity of California at Irvine, Department of Psychiatry and Human Behavior, USA \\ 'Northwestern University, Feinberg School of Medicine, Chicago, IL, USA \\ dUniversity of North Carolina, Department of Psychiatry, Chapel Hill, NC, USA
}

\begin{abstract}
Oxytocin (OT) and arginine vasopressin (AVP) are two small, related neuropeptide hormones found in many mammalian species, including humans. Dysregulation of these neuropeptides have been associated with changes in behavior, especially social interactions. We review how the OT and AVP systems have been investigated in Autism Spectrum Disorder (ASD), Prader-Willi Syndrome (PWS), Williams Syndrome (WS) and Fragile X syndrome (FXS). All of these neurodevelopmental disorders (NDD) are marked by social deficits. While PWS, WS and FXS have identified genetic mutations, ASD stems from multiple genes with complex interactions. Animal models of NDD are invaluable for studying the role and relatedness of OT and AVP in the developing brain. We present data from a FXS mouse model affecting the fragile X mental retardation 1 (Fmr1) gene, resulting in decreased OT and AVP staining cells in some brain regions. Reviewing the research about OT and AVP in these NDD suggests that altered OT pathways may be downstream from different etiological factors and perturbations in development. This has implications for ongoing studies of the therapeutic application of OT in NDD.
\end{abstract}

\section{Keywords}

Oxytocin; Vasopressin; Autism; Prader-Willi; Williams; Fragile X

\section{Introduction to OT and AVP neuropeptide hormones}

Oxytocin (OT) and arginine vasopressin (AVP) are small mammalian neuropeptides nine amino acids in length, which differ by only two amino acids. OT is produced primarily in hypothalamic nuclei, including the supraoptic (SON) and paraventricular nuclei (PVN). AVP is also synthesized in the PVN and SON. In males, additional brain regions including the amygdala and the bed nucleus of the stria terminalis (BNST) also produce AVP. OT and AVP of hypothalamic origins are transported from the SON and PVN to the mammalian

(C) 2014 Published by Elsevier B.V.

*Correspondence to: University of Minnesota, Wallin Medical Biosciences Building, 2101 6th Street SE, Minneapolis, MN 55455, USA. Fax: +612 273 9779. sjacob@umn.edu (S. Jacob). 
posterior pituitary by neurosecretion where they are released into the blood stream and act as hormones on target tissues. In addition, both OT and AVP are capable of moving throughout the central nervous system via diffusion in the cerebral spinal fluid (CSF; Neumann and Landgraf, 2012). The peptide-producing OT gene (OXT) is homologous with its evolutionarily related gene, vasopressin (AVP). The human OXT and AVP genes linked on chromosome 20p13 are separated by only 12 kilobases of DNA, and are positioned in opposite transcriptional orientations. Both have specific receptors, but their close evolutionary relationship permits cross-talk and interacting molecular systems. These neuropeptide hormones have receptors in various brain regions and throughout the body, including areas that are important for regulating social behavior and reactivity to stressors.

In both, the human and mouse genomes OT and AVP neuropeptide genes are located adjacently on the same chromosome. Often the blood levels of both hormones are highly correlated (Dai et al., 2012), suggesting a coordinated release. The receptors for both neuropeptides are localized in specific areas of the nervous system, especially in the brainstem. These brain regions influence social and adaptive behaviors, as well as regulate the hypothalamic-pituitary-adrenal axis (HPA) and autonomic nervous systems (Lim et al., 2005, 2004). Because OT and AVP are closely related and have the ability to act on the other's receptors, it has been proposed that they evolved to interact and sometimes have opposing physiological effects. For example, both hormones have been shown to affect the control of the autonomic nervous system, with OT having primarily parasympathetic actions and AVP serving as a central and peripheral regulatory component of the sympathetic nervous system and HPA axis (Kenkel et al., 2012; Sawchenko and Swanson, 1985). However, at high levels the neuropeptides can be partial agonists for their homologous receptors, which may result in AVP and OT pathways interacting (Chini et al., 1996).

Of particular importance in neurodevelopmental disorders (NDD) is the fact that OT and AVP can modulate social and repetitive behavior and other manifestations of anxiety and state regulation (Carter, 2007). Animal research has generally associated OT release or exposure with positive sociality, reduced anxiety, and lower levels of reactivity to stressors (Carter, 1998; Neumann and Landgraf, 2012). AVP influences anxiety, the regulation of HPA and stress responses. In general, central AVP is described as anxiogenic (Landgraf and Wigger, 2003). However, there is also evidence in rats that the effects of AVP are brain region specific and dose-dependent. For example, AVP may be anxiolytic if given in low doses (Appenrodt et al., 1998).

Mouse knockout (KO) studies of the OT receptor (OXTR) or OT regulators have found decreased social memory or recognition (Ferguson et al., 2000; Jin et al., 2007; Takayanagi et al., 2005). Oxtr KO mice also displayed decreased cognitive flexibility and a resistance to change of a learned pattern of behavior that is comparable to restricted/repetitive interests (Sala et al., 2011). Both social deficits and behavioral rigidity were ameliorated by OT administration (Sala et al., 2011). The finding that OT continues to have effects in Oxtr KO mice supports the hypothesis that OT can influence behavior through other receptors, especially the AVP receptors (e.g. AVPR1A and/or AVPR1B). Given the influence of these neuropeptides on brain regions affecting both social and repetitive behaviors, modulation of 
OT and AVP pathways are being explored as treatment targets for disorders, including Fragile X syndrome (FXS) and Autism Spectrum Disorders (ASD).

This and other research has set the stage for a series of recent studies on the effects of exogenous OT treatments in humans (Ebstein et al., 2012; Macdonald and Feifel, 2013). For example, intranasal OT (IN-OT) administration in healthy human males increased prosocial behaviors and trust, especially as measured by experimental economic games (Baumgartner et al., 2008; Kirsch, 2005; Kosfeld et al., 2005). IN-OT may also increase gaze towards the eye region of the face (Guastella et al., 2008), and has been associated with improved facial memory (Rimmele et al., 2009), enhanced salience of social cues (Shamay-Tsoory et al., 2009), and improved performance on the reading the mind in the eyes (RMET) task (Domes et al., 2007).

As previously reviewed, OT has been found to have anxiolytic effects improving social interactions, reducing fear, and improving the ability of healthy volunteers to interpret subtle social cues (Macdonald and Macdonald, 2010). In addition, OT dysfunction has been associated with neurop-sychiatric disorders such as autism in human studies (Domes et al., 2007; Ishak et al., 2011; Winslow and Insel, 2004). By 2010 there were over 20 OT administration studies, which included ASD, schizophrenia, postpartum depression, posttraumatic stress disorder (PTSD), and irritable bowel syndrome (Macdonald and Macdonald, 2010). There have been a growing number of studies investigating the ability of IN-OT to treat a range of neurobehavioral disorders due to the associations between IN-OT and alterations in social decision-making, processing of social stimuli, certain social behaviors such as eye contact, and social memory.

\section{Autism spectrum disorders}

In 1943, Leo Kanner described a male patient with repetitive behaviors-"stereotyped movements [and]...repetitions carried out in exactly the same way in which they had been performed originally" and difficulties with social communication-"he always seemed to be parroting what he had heard said to him at one time or another...Words to him had a specifically literal, inflexible meaning. He seemed unable to generalize, to transfer an expression to another similar object or situation" (Kanner, 1943). This group of symptoms, later extended and described in detail, is currently known as ASD. As described in the DSM-5 (American Psychiatric Association, 2013), ASD is characterized by persistent deficits in social communication and social interaction across multiple contexts, and the diagnosis requires the presence of restricted, repetitive patterns of behaviors, interests, or activities. ASD is a heritable (Bailey et al., 1995) and highly heterogeneous disorder, caused by familial genetic risks in addition to possible gene-environment interactions during early development (Chaste and Leboyer, 2012). Individuals with ASD often suffer with anxiety disorders, irritability or aggression, and come to clinical attention due to their difficulties at home and school related to their communication deficits and restricted interests. Unfortunately there are currently no approved medications to treat the social deficits or restricted, repetitive behaviors (RRB) that are the core symptoms of ASD. There is some evidence in animal and human studies that OT improves the core symptoms of ASD. 


\subsection{Intranasal andintravenous OT studies in ASD}

Currently medications for ASD concentrate on alleviating certain symptoms, but not the core features of ASD. Risperidone and aripiprazole may be used for irritability, whereas guanfacine and clonidine are used off label for aggression, and selective serotonin reuptake inhibitors (SSRI; i.e. escitalopram, fluoxetine, and sertraline) are used to treat anxiety (Jaselskis et al., 1992; McCracken et al., 2002; Owley et al., 2010). Recently, OT has been investigated as a target the treatment for ASD core symptoms, social deficits and RRB. Defined by DSM-5, restricted, repetitive patterns of behavior include stereotyped or repetitive motor movements, insistence on sameness, inflexible adherence to routines, or ritualized patterns of verbal or nonverbal behavior. Highly restricted, fixated interests that are abnormal in intensity or focus, and hyper- or hyporeactivity to sensory input or unusual interest in sensory aspects of the environment are also RRB.

Several studies, using intravenous OT or IN-OT, in patients with ASD have been conducted (Table 1). It has been shown that nonapeptides, like AVP, can be measured in CSF after intranasal administration (Born et al., 2002). Ease of giving intranasal drugs makes it preferred for most ASD studies, although more research needs to be conducted on how INOT reaches the brain and how it regulates receptors and neural pathways with different or chronic dosing strategies. Several studies have measured OT responses to single dose challenges in ASD (Andari et al., 2010; Guastella et al., 2010), while few have examined longer term treatment effects (Anagnostou et al., 2012). With varying administration and duration study protocols, studies have often focused on symptom subdomains or defined social tasks including: RRB (Hollander et al., 2003), emotion recognition (Dadds et al., in press; Guastella et al., 2010), affective speech comprehension (Hollander et al., 2007), and facial recognition (Domes et al., 2013).

Single dose studies, or challenges, have been utilized to study the acute and immediate effects of OT. An initial study in ASD examined the effects of a four-hour continuous dose of intravenous OT (Hollander et al., 2003). After one hour of infusion there was a decrease in RRB (repeating and touching). After four hours, 13 patients (86.7\%) versus six control subjects (40\%) had decreases in RRB. This study demonstrated that administration of OT led to a decrease in a core ASD symptom, RRB. More recently, a double-blind, randomized, placebo controlled study of IN-OT in 16 males with ASD (ages 12-19 years old) showed that a single IN-OT dose could improve the ability to recognize emotion, particularly in easy queries (Guastella et al., 2010). It is unclear whether emotion recognition performance goes back to baseline or pre-OT exposure after a single dose or if there are long-term learning effects.

Andari et al. (2010) also performed a single dose IN-OT study in 13 individuals with ASD and in age-matched controls to study the effect on social deficits. They researched the effects of IN-OT on trust and preference using a social ball tossing game (for greater detail of this task please see supplementary section of Andari et al., 2010). This group also assessed the visual scanning of faces under the influence of IN-OT. They found that patients given IN-OT had a significant preference for the "good player" (the computer player who tossed the ball back to the individual) that was similar to the control subjects also performing the task. This preference was further supported by the patients' reporting of 
trust, towards the "good player" after OT administration. Andari and colleagues also found that after IN-OT, patients increased eye gazing time on the socially informative region of the face. While single dose studies are valuable, evaluating long term effects of OT are essential to determine if OT has a therapeutic potential in ASD (Macdonald and Feifel, 2013).

Recently a five-day OT administration study was conducted during parent-child interaction training (Dadds et al., in press). Individuals with high functioning ASD received 12 or 24 IU (depending on the weight of the patient) IN placebo or IN-OT. The OT or placebo was administered once daily and RRB, emotion recognition, social interaction skills, and general behavioral adjustment were assessed. While improvements over time were detected in both OT and placebo, there were no differences observed between the two groups. Several proposed possible explanations for these null findings were: (1) emotion recognition was measured pre-post changes following multiple exposures versus while the patient was under the influence; (2) lower-order RRB respond to OT (Hollander et al., 2003), while higherorder RRB do not (Anagnostou et al., 2012); (3) increased eye gaze frequency is usually measured with artificial or computerized faces, while they had "real-life" interactions; (4) the OT receptor system disruptions in some patients with ASD may respond differently than in other ASD patients; and (5) differences between the studies regarding age and diagnostic characteristics of the sample. Studies pairing OT with a therapeutic activity or social training are highly needed, although design and outcome measures across studies will need to be similar in order to better interpret and compare results in ASD participants.

Investigating adults with ASD, Anagnostou et al. (2012) studied the safety and therapeutic effects of IN-OT with respect to two core symptom domains: social cognition and functioning, and RRB. They performed a randomized, double-blind, placebo-controlled parallel trial of IN-OT versus placebo. This was the first study to employ a treatment trial of daily administration of IN-OT in ASD. Overall, the IN-OT was well tolerated when given daily and no serious adverse effects were reported. This pilot study suggested therapeutic potential with daily administration of IN-OT in this population of adults with ASD. This sixweek study noted improvements in social cognition, quality of life, RRB, and some measures of emotional well-being with IN-OT, in essence, improvement in the core domains of ASD. It may be important to note that reports of individual differences in the response to IN-OT are increasingly observed, although sample sizes in studies will need to be larger to explore individual response variation.

\subsection{OT/AVP plasma levels in ASD}

The inability to directly access the brain's oxytocinergic pathways has constrained human research. Therefore, peripheral OT levels have been used as proxies for OT levels in the brain. A widely used measurement is plasma OT, although urine and salivary OT levels have also been explored in some studies. A range of studies have observed associations between peripheral OT/AVP levels and social stimuli (Kenkel et al., 2012; Schneiderman et al., 2012; Schradin et al., 2013; Seltzer et al., 2010; Wismer Fries et al., 2005; Zhong et al., 2012).

As early as 1996, it was suggested by a number of researchers, including Waterhouse et al. that dysfunction in the OT and AVP systems might contribute to the atypical social 
behaviors in ASD. Two years later by studying the OT plasma levels from 29 ASD and 30 age-matched typical control children, Modahl et al. (1998) reported low levels of plasma OT in the children with ASD. In another study, which utilized Wing's topology, children were classified as "aloof", "active but odd" and "overly formal" (Leekam et al., 1997). The lowest OT levels were found in the "aloof" subgroup. This suggested that the most severe sociallyaloof symptoms were associated with more OT dysfunction.

Building on these results with the same study sample, Green et al. (2001) conducted another OT study and examined the forms of the OT peptide found in affected and unaffected children. Their results showed that there was an increase in OT-X, the precursor for OT, as well as an increase in the ratio of OT-X/OT associated with the reduction in OT observed in the patients with ASD. During the normal production of OT, the extended form (OT-X) is cleaved by enzymatic activity to yield the active peptide OT. There was also a positive correlation between OT-X and checklist items associated with ASD including stereotypies; OT-X correlated negatively with an item describing abnormalities in comfort giving within the ASD group. Consequently, changes in OT processing, specifically a failure to completely process the prohormone OT-X, might lead to a deficiency in OT, thus exacerbating some of the symptoms of ASD, such as features of social deficits. To our knowledge this study has not been replicated. Furthermore, other studies often in older patients have failed to report an OT deficiency (Jansen et al., 2006; Miller et al., 2013). Future studies may benefit from the measurement of OT-X in addition to plasma OT given the diverse methods employed for assaying OT, and the finding that the failure to process this prohormone can lead to a deficiency of OT.

Recently, connections between peripheral OT/AVP levels and ASD were investigated (Miller et al., 2013). Miller et al. measured OT and AVP plasma levels in 75 boys and girls (40 high-functioning ASD, 35 typically developing) aged 8-18 years. Miller et al. not only reported associations between the plasma levels and ASD behaviors, but sex differences as well. Higher levels of OT were observed in all girls, and all boys had significantly higher levels of AVP. The higher OT levels were associated with greater anxiety in all girls, and with better pragmatic language in all subjects. Gender differences were also noted within the ASD sample. A positive association between AVP levels and RRB was reported in ASD girls, although a non-significant association with RRB was found in boys with ASD. Because of the limited number of girls affected by ASD, few other studies have sampled a large enough sample size of girls to investigate gender differences in OT plasma levels or response to exogenous administration.

Some studies have examined OT levels in addition to other hormones and blood biomarkers. In a study of adults with ASD, basal OT levels and heart rate were elevated in the ASD group compared to healthy controls. These adults with ASD showed normal cortisol responses to a public speaking task, but no change in norepinephrine, epinephrine, OT or AVP (Jansen et al., 2006). Recently, Hammock et al. (2012) analyzed correlations between the biomarkers of plasma OT and whole-blood serotonin (5-HT) levels in children and adolescents diagnosed with ASD and not on medications. Animal studies have shown that OT and 5-HT influence each other's release (Bagdy and Kalogeras, 1993; Jorgensen et al., 2003; Yoshida et al., 2009) and there have been many reports of hyperserotonemia within a 
subgroup of individuals with ASD (Abramson et al., 1989; Chugani et al., 1999; Kuperman et al., 1985; Leboyer et al., 1999; Leventhal et al., 1990; Schain and Freedman, 1961). OT and 5-HT were negatively correlated with each other in the Hammock et al. (2012) study. Whole blood 5-HT was found to be negatively correlated with age, having lower levels in adolescence than in childhood. This OT/5-HT relationship was especially prominent in children younger than 11 years old. Age may be an important covariate, because some studies do not find OT deficiencies or have reported higher than expected OT levels in their ASD samples (Jansen et al., 2006; Miller et al., 2013). OT like 5-HT may change after puberty according to recent data (Hammock et al., 2012).

Interest in parental bonding has led to the study of OT levels in parents of typical children, and more recently parents of children with ASD. An association between peripheral OT and parental care, both maternal and paternal, was reported by Feldman et al. (2012). When comparing parents and non-parents, parents were found to have higher levels of OT. Higher plasma OT levels were also associated with longer durations of gaze synchrony and reporting of greater parental care during the parent's childhood, while lower plasma OT corresponded to less parental touch. Subsequently, Xu et al. (2013) published a study comparing the OT and AVP plasma levels of mothers with and without ASD children in a Han population. They found that the mothers of ASD children had significantly lower plasma OT/AVP compared to the control mothers, as well as, a significant correlation between the plasma levels of the neuropeptides and the child's autistic behavior scores.

Over the last few years studies measuring peripheral OT have increased. As discussed in McCullough et al. (2013) and Szeto et al. (2011), the methodologies can lead to vastly different results (increased values, decreased values or values differing by an order of magnitude). For example, Modahl et al. (1998) performed plasma extractions and then radio-immunoassays (RIA) whereas Miller et al. (2013) utilized an enzyme immunoassay (EIA) with different plasma preparation methods. Additionally, there is also specific lab generated RIA versus commercial EIA and RIA kits. When manufacturer instructions are followed, values obtained have a similar order of magnitude, but it has been noted that some of these kits may also be detecting closely related metabolites. Note that studies often prepared samples differently with varying plasma processing/extraction methods and use of different assay techniques. Future research will need to determine if differences observed in the resultant OT levels of ASD studies reflect differences in the study populations (i.e. age) and/or the methods for assaying OT. ASD is a very heterogeneous disorder and OT level differences may be specific to clinical and etiological subgroups within the broader ASD population. In addition, there is variability of OT plasma levels across typical and healthy populations. The inherent U-shaped distribution (Zhong et al., 2012) observed in normative populations may also add to variability seen in OT measurements in ASD studies.

\subsection{OT and AVP animal and genetic studies in ASD}

The search for genes and biological risk factors contributing to ASD and its core symptoms has resulted in a range of human and animal model studies. Recently, several researchers have examined how the OT system is altered in various animal model or influences social and repetitive behaviors. For example, the BTBR T+tf/J (BTBR) mice have low social 
interactions, decreased vocalization in social settings and increased levels of repetitive selfgrooming, behavioral phenotypes similar to the core symptoms of ASD. Comparing BTBR to the standard inbred highly sociable mouse, C57BL/6J (B6), Silverman et al. (2010) found elevated OT in the PVN, plasma corticosterone (in the trunk), and glucocorticoid receptor (GR) mRNA in CA of the hippocampus in the BTBR. Measurements of the other neurochemicals (CRF in PVN, GR mRNA in CA2 and PVN) showed no differences between the strains.

Another model, the BALB/cJ, has low sociability across development (Brodkin, 2007). A substrain of the BALB/cJ, the BALB/cByJ mouse, was also characterized as a good ASD model (Brodkin, 2007; Moy et al., 2007). These mice displayed low sociability with intact olfaction, locomotor activity and relatively high levels of anxiety. Similarly, the C58/J mouse is another ASD mouse model described in 2010 by Ryan et al. (2010). These mice show low sociability and deficits in social communication. Most striking, however, is their abnormal RRB including increased rates of pivoting, back flipping, upright scrabbling and "jack-hammer" jumping. All the traits are found in both the males and females of the C58/J strain. Recently, the reactions of the BALB/cByJ and C58/J strains to OT administration were compared (Teng et al., 2013).

Teng et al. (2013) did not only note the different reactions to OT administration between $\mathrm{BALB} / \mathrm{cByJ}$ and $\mathrm{C} 58 / \mathrm{J}$, they also studied whether acute versus subchronic administration had differing outcomes (see paper for drug and experimental timeline). Both strains were administered OT peripherally via intraperitoneal administration. Acute administration in $\mathrm{BALB} / \mathrm{cByJ}$ showed no change in sociability, and RRB were not assessed in this timeline. However, in the subchronic regimen BALB/cByJ mice displayed a significant increase in social behaviors. Subchronic OT administration in the C58/J model also induced prosocial effects. In male mice these effects appeared two weeks post treatment, but the prosocial effects were evident in female mice sooner. Regarding RRB, Teng et al. observed a decrease in repetitive behaviors with increased self-grooming after an acute single dose of OT, in the C58/J mice. Most notably these studies have provided insight into how the genetic heterogeneity observed in humans may account for the wide variety and degree of behaviors seen in ASD. Additionally, the Teng et al. study highlighted how treatments can be dependent on both genotype and dose regimen. It is striking that all three mouse models of ASD have alterations in the OT system or respond to OT administration. This suggests that OT may be affected downstream in strains of mice that have different etiological factors influencing social and repetitive behaviors.

As the animal models have shown, the genetic heterogeneity of individuals with ASD could also account for the complexity of the disorder's genetic etiology. In a recent review (Ebstein et al., 2009), genetic polymorphisms of receptor and pathway regulators of OT and AVP, such as AVPR1a, OXTR, neurophysin I and II, and CD38 were discussed. In this review, Ebstein and colleagues presented preliminary data regarding their findings about CD38, a transmembrane glycoprotein involved in OT secretion and associated with OT plasma levels. The group genotyped 12 tag single nucleotide polymorphisms (SNPs) across CD38 in 170 ASD trios. IQ and social skills via Vineland Adaptive Behavior Scales (VABS) were assessed in the sample. They found a significant association between CD38 
SNPs and categorical ASD measures, assessed by the Autism Diagnostic Interview -

Revised (ADI-R; Lord et al., 1994) and Autism Diagnostic Observation Schedule - Generic (ADOS-G; Lord et al., 2000). Significance was also observed between VABS scores and four CD38 SNPs, haplotypes and VABS, and CD38 mRNA levels and VABS. Two studies in 2010 further supported a role for CD38 in ASD. Lerer and colleagues (2010) noted a reduced expression of CD38 in the lymphoblastoid cells of patients with ASD as compared to "unaffected" parents. Then Munesue et al. (2010), observed a CD38 SNP in association with high functioning ASD in some populations. In 2012, several CD38 studies were completed that looked at the association of CD38 and ASD. In particular, Sauer et al. (2012) researched the common CD38 variant, rs3796863, in healthy young men. This SNP stood out in the ASD association studies performed by Lerer et al. (2010) and Munesue et al. (2010). Data were attained in a double-blind placebo-controlled crossover design using INOT. The subjects performed two tasks following administration of OT or placebo: (1) a face matching task, and (2) a gaze processing task. They found that the men with the ASD risk allele had significantly slower reaction times (RT) during the face matching task and that it was specific to social versus non-social stimuli. IN-OT reduced RT in the risk group. Gaze processing did not yield any significant results. Functional MRI data also were attained as the subjects performed the tasks. Sauer et al. (2012) hypothesized decreased activity in the amygdala and fusiform brain regions of the risk allele group given the results of previous studies (Jemel et al., 2006; Schultz, 2005). Unexpectedly, they saw increased activation in the fusiform brain regions. This led them to conclude that while more research needs to be done to confirm their findings, the link between $\mathrm{CD} 38$, the processing of social information and ASD was further solidified.

Other researchers have looked directly at the OXTR gene, to find possible genetic links between OT and ASD. Wu et al. (2005) genotyped four SNPs across OXTR in 195 Chinese Han ASD trios. With Family Based Association Testing (FBAT), they revealed significant associations between ASD and two OXTR SNPs (rs2254298, rs53576). When the markers were combined to create haplotypes, significant associations were found for all markers and especially in haplotypes containing rs53576. Following up the Wu et al. study, Jacob et al. (2007) researched rs53576 and rs2254298 in a Caucasian sample with strictly defined autism. They genotyped the OXTR SNPs in 57 autism trios. In this sample a significant association was observed between diagnosis and rs2254298. While the $\mathrm{G}$ allele was more frequent than the A allele, of note was the overtransmission of the $\mathrm{G}$ allele to the autistic Caucasian probands versus over-transmission of the A allele in the Chinese Han sample. Additional studies by Yrigollen et al. (2008) and Campbell et al. (2011) continued to build an association between the OT system and ASD. Yrigollen and colleagues hypothesized that genes associated with affiliative, social, and/or bonding behaviors would also be associated with ASD and several of its symptoms. Therefore, they studied 177 ASD probands from 151 families and they found the statistical strength was in the OXTR results. Different OXTR SNPs were significantly associated with stereotyped behaviors, communication skills, the multivariate ADI phenotype and multi-measurement variable overall diagnosis. Also, there was a significant SNP in the OXT/AVP region associated with stereotyped behaviors. In 2011, Campbell and colleagues, utilizing a repository sample of 2333 individuals with ASD in 1238 pedigrees, analyzed 25 markers across OXTR and detected associations. Although 
these SNPs had previously been associated with ASD diagnosis in studies, they also looked at associations with subphenotype measurements of social impairments in ASD and found associations with their selected three SNPs and ADOS, ADI-R and SRS measurement. While the results of the studies indicate a need for further research, these genetic studies have laid the foundation linking OT, social tasks, and more broadly ASD.

\section{Prader-Willi syndrome and OT}

Prader-Willi syndrome (PWS) is a complex disorder with multisystem effects and a distinct behavioral phenotype. It occurs in approximately 1/10,000-1/30,000 births, and is initially characterized by severe infantile hypotonia and difficulty feeding, although later in infancy and into adolescence individuals with PWS often eat excessively and develop morbid obesity. Other characteristics of PWS include hypo-gonadism, short stature, small hands and feet and strabismus. The cognitive phenotype is marked by delayed motor and language development, and behavioral difficulties including compulsive behavior, stubbornness and temper tantrums (Bittel et al., 2007b; Cassidy et al., 2011). The many behavioral and psychiatric manifestations of PWS are evident in early childhood, and are characterized by hyperactivity, impulsivity, temper tantrums, emotional lability, anxiety and repetitive behavior (Borghgraef et al., 1990; Gross-Tsur et al., 2001; Whitman and Accardo, 1987). Often this phenotype is suggestive of ASD as well as attention deficit hyperactivity disorder (ADHD; Cassidy et al., 2012). Face processing is also altered in individuals with PWS, as they have difficulty reading facial expressions (Whittington and Holland, 2011).

The cause of PWS is the lack of expression of specific paternal genes located on chromosome 15q11.2-q13. Many of the genes expressed in this region come from the father, as those from the mother are normally inactivated. Consequently, either a lack of expression or absence of the paternal copy of the genes in this region leads to no expression (Saitoh et al., 1997). This may occur through microdeletions in the paternal chromosome, no copy of the paternal chromosome paired with two copies of the maternal chromosome-uni-parental disomy (UPD), or imprinting defects due to epige-netic causes (Cassidy et al., 2012). The genes expressed in this region have been studied at length to develop models of PWS and to delineate their roles in the different aspects of the PWS phenotype. Such studies are complicated by differences in the behavioral phenotype between individuals with deletions and those with UPD, as those with UPD have a less severe phenotype (Bittel et al., 2007a) and higher verbal IQ scores (Dimitropoulos et al., 2000).

While the deletion of no one individual gene has been found to cause PWS, research has shown that the lack of expression of multiple genes may be central to the syndrome's expression. Specifically, five polypeptide coding genes, namely MKRN3, MAGEL2, MAGED1, NECDIN and SNURF-SNRPRN, have been shown to be centrally involved in PWS. Animal models lacking one of these genes have been developed for Magel2 (Boccaccio et al., 1999), Maged1 (Dombret et al., 2012), Necdin (Lavi-Itzkovitz et al., 2012; Muscatelli et al., 2000) and Snurf (Tsai et al., 1999), although none of these individual gene disruption models completely recapitulates the PWS phenotype. 
Another line of approach to elucidate the physiological underpinnings of PWS has been to examine the OT system in individuals with PWS as well as in animal models. There is a deficit of OT producing neurons in the PVN of persons with PWS (Swaab et al., 1995), as well as lower levels of OT in CSF (Martin et al., 1998). IN-OT administration increases trust in others and decreases disruptive behavior in individuals with PWS (Tauber et al., 2011). In addition, administration of OT has also been shown to rescue behavior in a Magedl deletion model of PWS in which there is a decrease in hypothalamic OT (Dombret et al., 2012).

Although rescue was not attempted in the Necdin model, this mutant also shows a reduction in OT-producing neurons in the hypothalamus (Muscatelli et al., 2000). Consequently, there appears to be disruption of the OT system in individuals with PWS, which is recapitulated in different animal models. However, the exact mechanism of OT dysregulation is unclear.

\section{Williams syndrome and OT}

Williams syndrome (WS) was first described over 50 years ago (Williams et al., 1961). The first reported cases were focused on infants with hypercalcemia, developmental delays, cardiac malformations and dysmorphic facial features (Morris, 1993). However, better characterization of this syndrome has elucidated a distinct behavioral phenotype marked by an increased social drive paired with social fearlessness, poor judgment, difficulty forming peer relationships and high anxiety levels (Jarvinen et al., 2013). The cause of this disorder has been determined to be a deletion of 25-30 genes in the q11.23 region of either maternal or paternal chromosome 7 that spans approximately 1.5 megabases (Ewart et al., 1993; Korenberg et al., 2000; Lowery et al., 1995; Schubert, 2009). ELN, the gene for elastin, was the first deleted gene identified and its absence is indicative of a diagnosis of WS. While ELN disruption affects connective tissue, particularly of the aorta (Lowery et al., 1995), other genes such as LIMK1, CYLN2, GTF2I and GTF2IRD1 are involved in the behavioral phenotype of WS (Jarvinen-Pasley et al., 2008). The deletion of Gtf2i as well as Gtf2irdl has been shown to be involved in the social pheno-type specifically (Proulx et al., 2010; Sakurai et al., 2011).

The social phenotype associated with WS is striking due to the hypersociability of the affected individuals, as well as the preference for novel social over non-social stimuli (Jarvinen-Pasley et al., 2008; Jarvinen-Pasley et al., 2010) and increased eye contact (Mervis et al., 2003). In addition, the speech of individuals with WS is marked by high levels of socially engaging language as compared to controls or individuals with other developmental disorders such as Down Syndrome (Jarvinen-Pasley et al., 2010; Jarvinen et al., 2013). However, this does not translate into the development of social relationships as individuals show difficulty with social adjustment (Gosch and Pankau, 1994, 1997) and social judgment (Einfeld et al., 1997; Gosch and Pankau, 1997). In addition, affected individuals show deficits in social understanding, as evidenced by difficulty identifying affect (Gagliardi et al., 2003; Plesa-Skwerer et al., 2006) or other's mental states (Jarvinen-Pasley et al., 2008).

The high sociability of individuals with WS positions this syndrome as a good mechanism through which to understand the biological underpinnings of social behavior. Mouse models of WS include GTF2I deficient mice which display increased social interaction with novel mice and diminished social habituation (Sakurai et al., 2011) and Gtf2irdl deletions, which 
also show increased sociability (Proulx et al., 2010). Recently, de novo duplications of regions of 7q11.23 have been shown to be associated with ASD, whereas deletions of the same region lead to WS (Sanders et al., 2011). Such opposite effects of gene expression leading to markedly contrasting phenotypes raises the issue of dosage effects, but it should be noted that both ASD and WS phenotypes include abnormal social relationships, although through different mechanisms. Whereas individuals with WS show prolonged face gaze, those with ASD display reduced face gaze (Riby and Hancock, 2009). In addition, although children with WS and ASD display high levels of anxiety, individuals with ASD have higher levels of RRB as well as greater rates of social phobia and separation anxiety (Cascio et al., 2012).

As deletions or increased expression of genes in the region defining WS can lead to the contrasting phenotypes of WS or ASD, respectively, the possibility of dysregulation of OT was examined by Dai et al. (2012). They show increased baseline levels of OT in individuals with WS as compared to controls. Additionally, OT levels correlated positively with increased approach to strangers as well as decreased adaptive social behaviors. These results suggest that there may be a dose dependent effect of OT, as high levels may impair adaptive social behavior and may partly underlie the maladaptive social phenotype of WS.

\section{Fragile $X$ syndrome}

Named for the fragile site observed at Xq27.3, Fragile X Syndrome (FXS) is the most common inherited form of intellectual disability and the most common known single gene mutation associated with ASD (O'Donnell and Warren, 2002). Prevalence estimates range from $\sim 1$ case in 1000 to 1 case in 4000 males and has settled at 1 case in 6000 worldwide for females (Brown, 1990; Morton et al., 1997; Turner et al., 1996; Webb, 2010). This rare genetic disorder is characterized by specific physical features, as well as cognitive and behavioral phenotypes (Berry-Kravis et al., 2002, 2011; McLennan et al., 2011). The physical features can include: a long narrow face with large protruding ears, connective tissue abnormalities (i.e. hyperextensive joints), macroorchidism, macrocephaly, obesity (especially in young males), loose skin over the hands, a high arched palate, a vertical plantar crease and flat feet (Moy et al., 2009; Schapiro et al., 1995). The behavioral and social characteristics of FXS include: hyperactivity, attention difficulties, mood lability, compulsive and perseverative behaviors, some aggressive outbursts, learning deficits, developmental delays (including delayed speech development), social shyness and gaze avoidance, sensory hypersensitivity and withdrawal from touch, stereotypic movements and behaviors (i.e. hand flapping and rocking), poor motor coordination and echolalia (Hagerman et al., 2009; Hall, 2009; Hall et al., 2009; Moy et al., 2009). Many of these behaviors are linked to the anxiety level of the individual, a meaningful link because physiological studies have noted increased sympathetic and decreased parasympathetic activity and poor coordination between the systems in children and adolescents with FXS (Hall et al., 2009).

Cognitive tests have indicated a specific pattern of strengths and weaknesses. FXS individuals exhibit deficits in visuospatial tasks, quantitative skills, short-term and working memory, expressive language skills, sequential processing and executive function (Berry- 
Kravis et al., 2002; Cornish et al., 1999; Freund and Reiss, 1991; Hall et al., 2012; Kwon et al., 2001; Maes et al., 1994). Relative strengths include receptive language skills, visual memory, acquisition of factual information, imitation skills and gestalt processing (BerryKravis et al., 2002). This population also has susceptibility to certain other neuropsychiatric disabilities including ASD, ADHD, anxiety disorders, and neurological disorders such as epilepsy (Hessl et al., 2001; Pretorius et al., 1998). While the genetic cause of FXS has been found, the neurological basis of FXS symptoms continues to be unknown. MRI studies have found that individuals with FXS have enlarged lateral ventricles and increased caudate nucleus volumes relative to control subjects (Reiss et al., 1995). Anatomical studies of postmortem brains have revealed that dendritic spines of neocortical pyramidal neurons of FXS subjects are longer and thinner than those of matched controls, indicating perhaps the spines fail to mature normally in FXS patients (Hinton et al., 1991; Irwin et al., 2001; Rudelli et al., 1985; Wisniewski et al., 1991).

The majority of FXS patients have social anxiety and almost a third have symptoms that overlap with ASD (Hagerman et al., 2010). Published studies have reported the prevalence rate of FXS and autistic behaviors/ASD diagnosis to range from 25-47\%, however sample sizes are often small (Hatton et al., 2006; Morton et al., 1997). Like FXS and ASD, autistic symptoms are more common in males than females. Individuals with both FXS and ASD often have poorer developmental outcomes, lower cognitive abilities, lower levels of adaptive behavior and more problem behaviors than FXS individuals with fewer autistic behaviors. Of the individuals with FXS and autistic behaviors, 15-40\% of males and a few females meet the diagnostic criteria for ASD (Berry-Kravis et al., 2002). This group also tends to present with more severe communication deficits, stereotyped behaviors, and social anxiety versus social disinterest. Additionally, males present with more severe developmental delays than females. Overlapping behaviors between ASD and FXS, such as eye gaze avoidance (Hall et al., 2009), have led many scientists to study FXS as a way to understand and possibly target treatment for ASD. Some of the medical problems exhibited within this population include seizures (15-20\% of male children, usually limited to childhood), gastroesophageal reflux, failure to thrive in early infancy, hypotonia, recurrent otitis media and sinusitis, vision problems, cardiac valve prolapse, sleep disorders, and orthopedic issues and dental malocclusions. In the few girls studied with FXS, these medical problems are more variable (Berry-Kravis et al., 2002).

Diagnosis is based on DNA analysis that identifies the number of CGG repeats in the fragile X mental retardation 1 (FMR1) gene at the Xq27.3 site (Turner et al., 1996). In most affected individuals, this genetic disorder is caused by a trinucleotide (CGG) repeat expansion in the 5' untranslated (promoter) region of the FMRl gene. FMRI encodes the fragile X mental retardation protein (FMRP); a $69 \mathrm{kDa}$ protein found in most adult and fetal tissues, high concentrations are noted in the brain and testes. The expression of FMRP in the brain seems to be experience dependent and is produced in the soma and near the synapse (Berry-Kravis et al., 2002, 2011). FMRP is essential to the shaping of dendritic spines (Davidovic et al., 2011). The protein and network of mRNA targets and interacting proteins contribute to several forms of synaptic plasticity involving learning and memory processes, notably induced by activation of type I metabotropic gluta-mate receptor (mGluR; 
Davidovic et al., 2011). Mice lacking FMRP have impaired long-term potentiations in somatosen-sory cortex (Li et al., 2002), visual cortex (Wilson and Cox, 2007), olfactory cortex (Larson et al., 2005), cingulate cortex, and amygdala (Zhao et al., 2005) and enhanced long-term depression in hippocampus (Huber et al., 2002). In synapto-somal preparations, stimulation of mGluR results in a FMRP-dependent increase in protein synthesis (Weiler et al., 1997, 2004). It is hypothesized that a decrease in Fmrl functionally affects the protein interaction network with direct consequences on signaling cascade and cellular metabolism (Davidovic et al., 2011). There are two different FMRl mutations, full mutation and permutation (Goodrich-Hunsaker et al., 2011a, 2011b). Premutation, associated with Fragile X-associated tremor/ataxia syndrome (FXTAS; Wang et al., 2010), has a repeat length of 50-200 and does not usually cause mental deficits, but shyness, anxiety, and premature ovarian failure have been known to occur. Premutations do appear however to influence translation of FMRI mRNA (Feng et al., 1995). In many individuals with premutations, excess FMRI mRNA is produced, yet below normal FMRP is synthesized (Tassone et al., 2000a, 2000b) and may contribute to approximately $10 \%$ of male and $2-3 \%$ of female ASD cases (Wang et al., 2010). Upon female transmission the premuta-tion can become a full mutation. FXS is caused by full mutation which is 4200 trinucleotide repeats, and results in hypermethylation of the gene and transcriptional silencing (Tassone et al., 2000a). This creates an FMRP deficiency in the brain, which leads to FXS presentation (McLennan et al., 2011; Tassone et al., 2000a). Very rarely have other mutations in the FMRI gene involving deletions (Gedeon et al., 1992; Wohrle et al., 1992) or a point mutation (De Boulle et al., 1993) resulted in symptoms identical or even more severe than FXS.

\subsection{IN-OT as treatment for FXS}

Evidence has supported the investigation of OT as a treatment for FXS (Bartz and Hollander, 2006; Hall et al., 2012; Hollander et al., 2007). As described earlier OT, released endogenously or given exogenously, has been associated with positive social behaviors, reductions in anxiety, obses-siveness and stress reactivity, the central release of AVP and other peptides such as corticotropin-releasing factor, and may serve to counter the defensive behavioral strategies associated with stressful experiences (Carter, 2007). However, similar to ASD, available treatments for FXS focus on managing symptoms: stimulants are prescribed for attention deficit and hyperactivity; SSRI and antipsychotics treat aggression associated with anxiety; and carbamazepine are used for treatment of seizures (Hampson et al., 2011). Currently, there are no treatments on the market targeting the molecular abnormalities of FXS (Gurkan and Hagerman, 2012). Recent studies have begun to investigate IN-OT due to the autistic-like behaviors observed in FXS, and the social and anxiolytic effects of OT.

As of the time of publication, very few studies had been performed to research the effect of IN-OT on FXS, especially in humans. One such study was conducted by Hall et al. (2012). They set up a randomized double-blind placebo-controlled single-dose trial performed with intranasal administration of placebo, 24IU OT and 48 IU OT. Studying eight low functioning males between the ages of 13 and 28 years with FXS, they hypothesized that the prosocial and anxiolytic effects of OT would reduce, if not alleviate, socially inappropriate 
behaviors and social anxiety. The group collected eye gaze frequency, heart rate, respiratory sinus arrhythmia, heart rate variability (HRV) during two social challenges (10 min total in length), and salivary cortisol levels before and after the challenge, which was conducted 50 min after OT administration.

Confirmation of the hypothesis that OT would have beneficial consequences in FXS would be an increase in eye gaze frequency, a reduction in physiological arousal, and a decrease in salivary cortisol. The researchers observed a significant main effect with OT. As compared to placebo, 24IU OT led to a significant increase in eye gaze frequency. They found a significant decrease in salivary cortisol for the $48 \mathrm{IU}$ dose as compared to placebo. No effects were observed in the physiological measurements (HR, HRV, and RSA), however, given the small sample and heterogeneous population additional research is needed. Based upon the data to date, Hall and colleagues hypothesized that in FXS administration of OT may dampen amygdala reactivity towards social stimuli that causes anxiety (Kirsch et al., 2005; Petrovic et al., 2008), decrease HPA axis activation, and increase social motivation (Witt and Insel, 1992; Witt et al., 1992).

\subsection{Animal models: a way to look at moderators of neurodevelopmental pathways and outcomes?}

Animal models have proven indispensable in the understanding of diseases and disorders, and in the development of pharmaceuticals used to treat them. The quality of an animal model is ascertained based on how well it can meet certain criteria of validity. Three of these criteria are construct, face and predictive validity (Bernardet and Crusio, 2006). How well the model's behavioral traits resemble the core traits of the disorder is face validity. Predictive validity is established when a drug reduces or improves symptoms in both the model and human. Construct validity is the "quality" of the model, its ability to accurately measure or represent what it claims to be measuring (Cronbach and Meehl, 1955). There are several FXS animal models, three in mice and a drosophila model that meet multiple criteria.

Two homologous genes to Fmrl in vertebrates are Fxrl (fragile $\mathrm{X}$ related gene) and $F x r 2$. The genes are highly homologous at the protein structure level and bind mRNA and bind to FMRP. Their proteins, FXR1P and FXR2P are both expressed in the brain and specifically in cell bodies, but they are also found in the dendrites near the synapse. Both Fxrl and Fxr2 KO mice have been produced. FXR1P deficient $\left(\mathrm{Fxr}^{-/-}\right)$mice die within $24 \mathrm{~h}$ of birth, while heterozygous mice exhibit abnormal limb musculature. Fxr2 KO have a normal lifespan, learning deficits similar to Fmrl KO, and circadian rhythm deficits (Berry-Kravis et al., 2011). The fruit fly model, a mutant lacking dFmr1 (also known as dFxr) protein, exhibits overextension of neurites during development of mushroom bodies (brain region linked with memory) and have a behavioral phenotype that includes circadian rhythm abnormalities and altered courtship behavior (Berry-Kravis et al., 2011; Gatto and Broadie, 2009).

One of the best characterized animal models of FXS was developed in 1994 by the DutchBelgian Fragile X Consortium. This mouse model, which lacks FMRP throughout its lifespan, corresponds to the molecular endpoint of the human disease. This mouse was 
created by inserting a neomycin cassette into exon 5 of the murine $F m r l$ gene. The insert disrupts the transcription of Fmrl mRNA causing an absence of FMRP. Even though the cause may not be identical, this mouse model exhibits behavioral similarities to FXS. Fmrl $\mathrm{KO}$, in comparison to the wild-type (WT) strain, are described as having lower than normal levels of initial social interactions (Mineur et al., 2006), fail to show a preference for social novelty, and display inappropriate social responses (Pietropaolo et al., 2011). In contrast, the OT and AVP knockout (OTKO or AVPKO) mice display high levels of social contact that does not diminish over time, but also fail to show indication of familiarity (Crawley et al., 2007).

While macroorchidism is observed in the Fmrl KO animals (Bakker et al., 1994) as well as in FXS patients, the behavioral patterns differ between the patients and the KO. By most accounts Fmrl KO mice appear to have relatively normal behavior, but research has shown that the behavioral and cognitive deficits of the $\mathrm{KO}$ are actually quite subtle and parallel FXS patients (Berry-Kravis et al., 2002; D’Hooge et al., 1997; Paradee et al., 1999; Peier et al., 2000). Among the behavioral phenotypes displayed in Fmrl KO are deficits in object recognition memory (including a failure to habituate to objects), and impairment of spatial memory (Mineur et al., 2002).

Several studies indicate that $F m r l \mathrm{KO}$ mice are hyperactive and show indications of increased anxiety (Bakker et al., 1994; Mineur et al., 2002; Spencer et al., 2005) and sensory hyperre-sponsiveness, especially to auditory stimuli (Chen and Toth, 2001; Frankland et al., 2004; Nielsen et al., 2002). Loud tones may induce audiogenic seizures. Fmrl KO also exhibit abnormal social interactions, including a general reduction in social contact and a failure to show social recognition (Bernardet and Crusio, 2006; Mineur et al., 2006; Spencer et al., 2005; Yan et al., 2004). In some tasks there is variability in the results (i.e. complex visual and auditory discriminant tasks and activity level in an open field). The symptom variability among mouse models for FXS may be due to differences in genetic backgrounds. A similar hypothesis has been proposed to explain the variability observed in the symptoms of FXS patients. For example, in research by Pietropaolo et al. (2011), the validity of the Fmrl KO mouse on the B6 background was tested against WT and Fmrl KO on the FVB background. They found the Fmrl KO on the B6 background to be a good model for FXS and a suitable model for ASD (Pietropaolo et al., 2011; Yan et al., 2004).

These mice also have neuropathologic phenotypes that are similar to FXS patients including density of dendritic spines of pyramidal neurons in the visual and somatosensory cortices that are greater in adult Fmrl KO than WT. Some brain areas, in both mice Fmrl KO mice and FXS patients, have spines that appear similar to developing versus mature spines (Berry-Kravis et al., 2002). Absence of FMRP in both humans and mice results in improper development of dendritic spines on cortical pyramidal neurons (Comery et al., 1997; Irwin et al., 2000; Irwin et al., 2001; Irwin et al., 2002). The use of the Fmrl KO mouse has also provided some insight into the normal cellular function of FMRP. The subtle cognitive deficits of Fmrl KO mice present difficulties for preclinical testing of potential treatments, and highlight how complex the relationship between the mouse and human phenotypes are. One possibility is that the cognitive processes in which FMRP plays a vital role in humans are poorly developed in mice; thus mice lacking FMRP are not particularly disabled, at least 
compared to severely-affected patients. A second possibility is that other proteins can compensate for FMRP in the mouse but not in the human. Third, the behavioral paradigms thus far applied to the mouse model do not efficiently assay or correlate with the cognitive domains most affected in individuals with FXS.

\subsection{Examining OT in neurodevelopmental animal models: a way to examine early effects?}

Below we present preliminary data examining the OT and AVP systems in a mouse model in order to learn more about FXS pathway interactions during development. The methods used in this study are described in the text for Fig. 1. These preliminary results, based upon counts of immune-reactive cells, suggest a reduction in both OT-positive (Fig. 1) and AVPpositive (Fig. 2) cells in the PVN of Fmrl KO as compared to WT (Table 2). A trend, although not significant, towards lower OT-positive cells was also noted in the SON (Table 3). To analyze possible differences in the OXTR, the abundance of OXTR-immunoreactive cells were also measured in the hippocampus, retrosplenial granular and piriform cortices. None of these areas showed a significant difference in OXTR-immunoreactive cell density as compared to WT mice ( $p>0.05)$. The PVN is an important component of the HPA axis, and reductions in OT-positive and AVP-positive cells of the PVN might be associated with deficits in the capacity to regulate emotional reactivity. Earlier work in voles has suggested that either OT or AVP may support a general tendency toward social contact (Cho et al., 1999). Thus, the absence of either OT or AVP in the presence of the other did not produce an "asocial" animal. However, selective social preferences, such as those necessary for pair bond formation, appear to require stimulation of both OT and AVP receptors. The importance of both OT and AVP to selective behaviors also may be supported by the fact that mice "knocked-out" for either OT or the OXTR no longer exhibited selective social memory (Young and Flanagan-Cato, 2012).

Although the preliminary data shown here for Fmrl KO mice need to be replicated in a larger sample and in other animal models, we include these findings as an example of possible approaches to examining the role of peptides including, OT and AVP, in molecularly characterized genetic syndromes. Work across these models also could provide additional insight regarding the role of OT and AVP in early development, especially in syndromes in which atypical trajectories in social development occur.

\section{Conclusion and next steps}

Each of the disorders described here (ASD, PWS, WS and FXS) is unique and each condition is characterized by atypical social behaviors, often with a tendency toward high levels of anxiety. Given the importance of OT and AVP to mammalian social behaviors and anxiety, the neuropeptides' investigative value in these syndromes is not unexpected. This review summarized the possible role of OT in these NDD (Table 4) through experiments conducted by others and ourselves.

Each of these early developmental disorders displays alterations in the OT system. These changes may impact behavior and emotional regulation through a variety of molecular and neuroendocrine pathways. For example, our preliminary data suggests a decreased number of OT-positive and AVP-positive cells in the PVN of Fmrl KO mice, a mouse model for 
FXS. Individuals with PWS have shown lower levels of OT in CSF (Martin et al., 1998) and fewer OT producing cells in the PVN (Swaab et al., 1995). A subgroup of ASD affected children also appeared to have lower plasma OT levels (Modahl et al., 1998). In contrast WS, which is characterized by hypersociability, had a positive correlation between OT levels and increased stranger approach and decreased adaptive social behavior (Dai et al., 2012).

At present, the largest concentration of studies on the role of dysregulated OT pathways has been conducted in ASD. However, as new data are emerging it is striking that other disorders with phenotypes marked by abnormal social behavior, as well as anxiety (in some cases manifested by RRB) also appear to have abnormalities found within the OT system. For example, as in ASD, individuals with PWS have difficulty with social competence (Dimitropoulos et al., 2013), are aloof and avoid eye contact (Dimitropoulos et al., 2009). Furthermore, RRB is also evidenced in PWS (Greaves et al., 2006), although to a lesser degree than in ASD as measured by the Repetitive Behavior Scale-Revised (RBS-R; Flores et al., 2011). A subset of the genetic region associated with PWS is also associated with an increased risk for ASD, as maternally inherited duplications of the 15q11-13 region are associated with 1-3\% of ASD cases (Bolton et al., 2001; Cook et al., 1997; Vorstman et al., 2006).

WS and ASD also share commonalities as both are marked by abnormal social phenotypes and anxiety. However, unlike PWS, individuals with WS show a phenotype that is markedly different from ASD. Although both groups are at risk for anxiety, individuals with ASD show higher levels of social phobia and separation anxiety, as well as higher rates of RRB. However, individuals with WS have higher scores on measures of generalized anxiety (Rodgers et al., 2012). WS is characterized by an increase in OT levels (Dai et al., 2012), as well as a deletion of the 7q11.23 region, as opposed to a de novo duplication which leads to ASD (Sanders et al., 2011). It is likely that features of ASD and WS are manifestations of gene dosage effects on similar behaviors. Studies of FXS and ASD mechanisms may also inform each other, as mutations in mGluR5 can contribute to the diagnosis of FXS or ASD, and mGluR5 antagonists have shown promise in alleviating ASD symptoms in mouse models (Silverman et al., 2012) as well as FXS pathology. Due to the rarity of these disorders and the complex animal models needed to study them, many of these experiments have small sample sizes. However, these studies remain significant and together provide a motivation and direction for future research in NDD, especially disorders with dysfunctional social behaviors as a symptom.

As summarized in this review, the dysregulation of the OT system in animals and humans is associated with marked deficits in social behavior as well as anxiety. This commonality across multiple NDD may indicate a shared OT pathway that is affected during development. The use of animal models, particularly those developed for FXS, WS and PWS will provide insight into such a pathway, as these disorders have well characterized genetics. In contrast, there are over a 103 disease genes and 44 genomic loci reported to be involved in ASD (Betancur, 2011). However, unlike ASD research, there is a lack of human data on the pathophysiology of FXS, WS and PWS, and pharmacological interventions. Ideally, scientists want to identify specific molecular pathways to target distinct syndromes 
and disorders for treatment. However, many effective medical treatments, such as drugs for hypertension, modulate common neurochemical or hormone pathways that are downstream from etiologically contributing factors. Combining the strengths of human and animal model studies across these NDD may provide important clues into the developmental role of OT. Additionally, as general mechanisms underlying social and emotional behaviors are specified, it may become possible to elucidate the complex neurophysiology of and create treatment targets for FXS, PWS, WS and ASD.

\section{Acknowledgments}

This work was supported in part by NIH K23MH082121 (SJ). The authors would like to acknowledge Dr. John Larson for his contribution of the Fmrl KO mice. We would also like to thank Jeanine Leary and Jennifer Speak for their assistance in manuscript formatting and preparation.

\section{REFERENCES}

Abramson RK, Wright HH, Carpenter R, Brennan W, Lumpuy O, Cole E, Young SR. Elevated blood serotonin in autistic probands and their first-degree relatives. J. Autism Dev. Disord. 1989; 19:397407. [PubMed: 2793785]

American Psychiatric Association. Diagnostic and Statistical Manual of Mental Disorders. 5th ed.. Arlington, VA: American Psychiatric Publishing; 2013.

Anagnostou E, Soorya L, Chaplin W, Bartz J, Halpern D, Wasserman S, Wang AT, Pepa L, Tanel N, Kushki A, Hollander E. Intranasal oxytocin versus placebo in the treatment of adults with autism spectrum disorders: a randomized controlled trial. Mol. Autism. 2012; 3:16. [PubMed: 23216716]

Andari E, Duhamel JR, Zalla T, Herbrecht E, Leboyer M, Sirigu A. Promoting social behavior with oxytocin in high-functioning autism spectrum disorders. Proc. Natl. Acad. Sci. USA. 2010; 107:4389-4394. [PubMed: 20160081]

Appenrodt E, Schnabel R, Schwarzberg H. Vasopressin administration modulates anxiety-related behavior in rats. Physiol. Behav. 1998; 64:543-547. [PubMed: 9761230]

Bagdy G, Kalogeras KT. Stimulation of 5-HT1A and 5-HT2/ 5-HT1C receptors induce oxytocin release in the male rat. Brain Res. 1993; 611:330-332. [PubMed: 8334526]

Bailey A, Le Couteur A, Gottesman I, Bolton P, Simonoff E, Yuzda E, Rutter M. Autism as a strongly genetic disorder: evidence from a British twin study. Psychol. Med. 1995; 25:63-77. [PubMed: 7792363]

Bakker CE, Verheij C, Willemsen R, Vanderhelm R, Oerlemans F, Vermey M, Bygrave A, Hoogeveen AT, Oostra BA, Reyniers E, Deboulle K, Dhooge R, Cras P, Vanvelzen D, Nagels G, Martin JJ, Dedeyn PP, Darby JK, Willems PJ. Fmr1 knockout mice-a model to study fragile-X mental-retardation. Cell. 1994; 78:23-33. [PubMed: 8033209]

Bartz JA, Hollander E. The neuroscience of affiliation: forging links between basic and clinical research on neuropeptides and social behavior. Horm. Behav. 2006; 50:518-528. [PubMed: 16884725]

Baumgartner T, Heinrichs M, Vonlanthen A, Fischbacher U, Fehr E. Oxytocin shapes the neural circuitry of trust and trust adaptation in humans. Neuron. 2008; 58:639-650. [PubMed: 18498743]

Bernardet M, Crusio WE. Fmr1 KO mice as a possible model of autistic features. Sci. World J. 2006; 6:1164-1176.

Berry-Kravis E, Grossman AW, Crnicz LS, Greenough WT. Understanding fragile X syndrome. Curr. Paediatr. 2002; 12:316-324.

Berry-Kravis E, Knox A, Hervey C. Targeted treatments for fragile X syndrome. J. Neurodev. Disord. 2011; 3:193-210. [PubMed: 21484200]

Betancur C. Etiological heterogeneity in autism spectrum disorders: more than 100 genetic and genomic disorders and still counting. Brain Res. 2011; 1380:42-77. [PubMed: 21129364] 
Bittel DC, Kibiryeva N, McNulty SG, Driscoll DJ, Butler MG, White RA. Whole genome microarray analysis of gene expression in an imprinting center deletion mouse model of Prader-Willi syndrome. Am. J. Med. Genet. A. 2007a; 143:422-429. [PubMed: 17036336]

Bittel DC, Kibiryeva N, Sell SM, Strong TV, Butler MG. Whole genome microarray analysis of gene expression in Prader-Willi syndrome. Am. J. Med. Genet. A. 2007b; 143:430-442. [PubMed: 17236194]

Boccaccio I, Glatt-Deeley H, Watrin F, Roeckel N, Lalande M, Muscatelli F. The human MAGEL2 gene and its mouse homologue are paternally expressed and mapped to the Prader-Willi region. Hum. Mol. Genet. 1999; 8:2497-2505. [PubMed: 10556298]

Bolton PF, Dennis NR, Browne CE, Thomas NS, Veltman MW, Thompson RJ, Jacobs P. The phenotypic manifestations of interstitial duplications of proximal $15 q$ with special reference to the autistic spectrum disorders. Am. J. Med. Genet. 2001; 105:675-685. [PubMed: 11803514]

Borghgraef M, Fryns JP, Van Den Berghe H. Psychological profile and behavioural characteristics in 12 patients with Prader-Willi syndrome. Genet. Couns. 1990; 1:141-150. [PubMed: 1706926]

Born J, Lange T, Kern W, McGregor GP, Bickel U, Fehm HL. Sniffing neuropeptides: a transnasal approach to the human brain. Nat. Neurosci. 2002; 5:514-516. [PubMed: 11992114]

Brodkin ES. BALB/c mice: low sociability and other phenotypes that may be relevant to autism. Behav. Brain Res. 2007; 176:53-65. [PubMed: 16890300]

Brown WT. The fragile X: progress toward solving the puzzle. Am. J. Hum. Genet. 1990; 47:175-180. [PubMed: 1974122]

Campbell DB, Datta D, Jones ST, Batey Lee E, Sutcliffe JS, Hammock EA, Levitt P. Association of oxytocin receptor (OXTR) gene variants with multiple phenotype domains of autism spectrum disorder. J. Neurodev. Disord. 2011; 3:101-112. [PubMed: 21484202]

Carter CS. Neuroendocrine perspectives on social attachment and love. Psychoneuroendocrinology. 1998; 23:779-818. [PubMed: 9924738]

Carter CS. Sex differences in oxytocin and vasopressin: implications for autism spectrum disorders? Behav. Brain Res. 2007; 176:170-186. [PubMed: 17000015]

Cascio CJ, Foss-Feig JH, Heacock JL, Newsom CR, Cowan RL, Benningfield MM, Rogers BP, Cao A. Response of neural reward regions to food cues in autism spectrum disorders. J. Neurodev. Disord. 2012; 4:9. [PubMed: 22958533]

Cassidy SB, Schwartz S, Miller JL, Driscoll DJ. Prader- Willi syndrome. Genet. Med. 2011

Cassidy SB, Schwartz S, Miller JL, Driscoll DJ. Prader- Willi syndrome. Genet. Med. 2012; 14:10-26. [PubMed: 22237428]

Chaste P, Leboyer M. Autism risk factors: genes, environment, and gene-environment interactions. Dialogues Clin. Neurosci. 2012; 14:281-292.

Chen L, Toth M. Fragile X mice develop sensory hyperreactivity to auditory stimuli. Neuroscience. 2001; 103:1043-1050. [PubMed: 11301211]

Chini B, Mouillac B, Balestre MN, Trumpp-Kallmeyer S, Hoflack J, Hibert M, Andriolo M, Pupier S, Jard S, Barberis C. Two aromatic residues regulate the response of the human oxytocin receptor to the partial agonist arginine vasopressin. FEBS Lett. 1996; 397:201-206. [PubMed: 8955347]

Cho MM, DeVries AC, Williams JR, Carter CS. The effects of oxytocin and vasopressin on partner preferences in male and female prairie voles (Microtus ochrogaster). Behav. Neurosci. 1999; 113:1071-1079. [PubMed: 10571489]

Chugani DC, Muzik O, Behen M, Rothermel R, Janisse JJ, Lee J, Chugani HT. Developmental changes in brain serotonin synthesis capacity in autistic and nonautistic children. Ann. Neurol. 1999; 45:287-295. [PubMed: 10072042]

Comery TA, Harris JB, Willems PJ, Oostra BA, Irwin SA, Weiler IJ, Greenough WT. Abnormal dendritic spines in fragile $\mathrm{X}$ knockout mice: maturation and pruning deficits. Proc. Natl. Acad. Sci. USA. 1997; 94:5401-5404. [PubMed: 9144249]

Cook EH Jr, Lindgren V, Leventhal BL, Courchesne R, Lincoln A, Shulman C, Lord C, Courchesne E. Autism or atypical autism in maternally but not paternally derived proximal $15 \mathrm{q}$ duplication. Am. J. Hum. Genet. 1997; 60:928-934. [PubMed: 9106540]

Cornish KM, Munir F, Cross G. Spatial cognition in males with Fragile-X syndrome: evidence for a neuropsychological phenotype. Cortex. 1999; 35:263-271. [PubMed: 10369098] 
Crawley JN, Chen T, Puri A, Washburn R, Sullivan TL, Hill JM, Young NB, Nadler JJ, Moy SS, Young LJ, Caldwell HK, Young WS. Social approach behaviors in oxytocin knockout mice: comparison of two independent lines tested in different laboratory environments. Neuropeptides. 2007; 41:145-163. [PubMed: 17420046]

Cronbach LJ, Meehl PE. Construct validity in psychological tests. Psychol. Bull. 1955; 52:281-302. [PubMed: 13245896]

D’Hooge R, Nagels G, Franck F, Bakker CE, Reyniers E, Storm K, Kooy RF, Oostra BA, Willems PJ, De Deyn PP. Mildly impaired water maze performance in male Fmr1 knockout mice. Neuroscience. 1997; 76:367-376. [PubMed: 9015322]

Dadds MR, Macdonald E, Cauchi A, Williams K, Levy F, Brennan J. Nasal oxytocin for social deficits in childhood autism: a randomized controlled trial. J. Autism Dev. Disord. in press [Epub ahead of print].

Dai L, Carter CS, Ying J, Bellugi U, Pournajafi-Nazarloo H, Korenberg JR. Oxytocin and vasopressin are dysregulated in Williams syndrome, a genetic disorder affecting social behavior. PLoS One. 2012; 7:e38513. [PubMed: 22719898]

Davidovic L, Navratil V, Bonaccorso CM, Catania MV, Bardoni B, Dumas ME. A metabolomic and systems biology perspective on the brain of the fragile X syndrome mouse model. Genome Res. 2011; 21:2190-2202. [PubMed: 21900387]

De Boulle K, Verkerk AJ, Reyniers E, Vits L, Hendrickx J, Van Roy B, Van den Bos F, de Graaff E, Oostra BA, Willems PJ. A point mutation in the FMR-1 gene associated with fragile X mental retardation. Nat. Genet. 1993; 3:31-35. [PubMed: 8490650]

Dimitropoulos A, Feurer ID, Roof E, Stone W, Butler MG, Sutcliffe J, Thompson T. Appetitive behavior, compulsivity, and neurochemistry in Prader-Willi syndrome. Ment. Retard. Dev. Disabil. Res. Rev. 2000; 6:125-130. [PubMed: 10899805]

Dimitropoulos A, Ho AY, Klaiman C, Koenig K, Schultz RT. A comparison of behavioral and emotional characteristics in children with autism, Prader-Willi syndrome, and Williams syndrome. J. Ment. Health Res. Intellect. Disabil. 2009; 2:220-243.

Dimitropoulos A, Ho A, Feldman B. Social responsiveness and competence in Prader-Willi syndrome: direct comparison to autism spectrum disorder. J. Autism Dev. Disord. 2013; 43:103-113. [PubMed: 22576167]

Dombret C, Nguyen T, Schakman O, Michaud JL, Hardin-Pouzet H, Bertrand MJ, De Backer O. Loss of Maged1 results in obesity, deficits of social interactions, impaired sexual behavior and severe alteration of mature oxytocin production in the hypothalamus. Hum. Mol. Genet. 2012; 21:47034717. [PubMed: 22865874]

Domes G, Heinrichs M, Michel A, Berger C, Herpertz S. Oxytocin improves "Mind-Reading" in humans. Biol. Psychiatry. 2007; 61:731-733. [PubMed: 17137561]

Domes G, Sibold M, Schulze L, Lischke A, Herpertz SC, Heinrichs M. Intranasal oxytocin increases covert attention to positive social cues. Psychol. Med. 2013; 43:1747-1753. [PubMed: 23146328]

Ebstein RP, Israel S, Lerer E, Uzefovsky F, Shalev I, Gritsenko I, Riebold M, Salomon S, Yirmiya N. Arginine vasopressin and oxytocin modulate human social behavior. Ann. N. Y. Acad. Sci. 2009; 1167:87-102. [PubMed: 19580556]

Ebstein RP, Knafo A, Mankuta D, Chew SH, Lai PS. The contributions of oxytocin and vasopressin pathway genes to human behavior. Horm. Behav. 2012; 61:359-379. [PubMed: 22245314]

Einfeld SL, Tonge BJ, Florio T. Behavioral and emotional disturbance in individuals with Williams syndrome. Am. J. Ment. Retard. 1997; 102:45-53. [PubMed: 9241407]

Ewart AK, Morris CA, Atkinson D, Jin W, Sternes K, Spallone P, Stock AD, Leppert M, Keating MT. Hemizygosity at the elastin locus in a developmental disorder, Williams syndrome. Nat. Genet. 1993; 5:11-16. [PubMed: 7693128]

Feldman R, Zagoory-Sharon O, Weisman O, Schneiderman I, Gordon I, Maoz R, Shalev I, Ebstein RP. Sensitive parenting is associated with plasma oxytocin and polymorphisms in the OXTR and CD38 genes. Biol. Psychiatry. 2012; 72:175-181. [PubMed: 22336563]

Feng Y, Zhang F, Lokey LK, Chastain JL, Lakkis L, Eberhart D, Warren ST. Translational suppression by trinucleotide repeat expansion at FMR1. Science. 1995; 268:731-734. [PubMed: 7732383] 
Ferguson JN, Young LJ, Hearn EF, Matzuk MM, Insel TR, Winslow JT. Social amnesia in mice lacking the oxytocin gene. Nat. Genet. 2000; 25:284-288. [PubMed: 10888874]

Flores CG, Valcante G, Guter S, Zaytoun A, Wray E, Bell L, Jacob S, Lewis MH, Driscoll DJ, Cook EH Jr, Kim SJ. Repetitive behavior profiles: consistency across autism spectrum disorder cohorts and divergence from Prader-Willi syndrome. J. Neurodev. Disord. 2011; 3:316-324. [PubMed: 21881965]

Frankland PW, Wang Y, Rosner B, Shimizu T, Balleine BW, Dykens EM, Ornitz EM, Silva AJ. Sensorimotor gating abnormalities in young males with fragile $\mathrm{X}$ syndrome and Fmr1-knockout mice. Mol. Psychiatry. 2004; 9:417-425. [PubMed: 14981523]

Freund LS, Reiss AL. Cognitive profiles associated with the fra $(\mathrm{X})$ syndrome in males and females. Am. J. Med. Genet. 1991; 38:542-547. [PubMed: 2063895]

Gagliardi C, Frigerio E, Burt DM, Cazzaniga I, Perrett DI, Borgatti R. Facial expression recognition in Williams syndrome. Neuropsychologia. 2003; 41:733-738. [PubMed: 12591030]

Gatto CL, Broadie K. Temporal requirements of the fragile $\mathrm{x}$ mental retardation protein in modulating circadian clock circuit synaptic architecture. Front. Neural Circuits. 2009; 3:8. [PubMed: 19738924]

Gedeon AK, Baker E, Robinson H, Partington MW, Gross B, Manca A, Korn B, Poustka A, Yu S, Sutherland GR, et al. Fragile X syndrome without CCG amplification has an FMR1 deletion. Nat. Genet. 1992; 1:341-344. [PubMed: 1302032]

Goodrich-Hunsaker NJ, Wong LM, McLennan Y, Srivastava S, Tassone F, Harvey D, Rivera SM, Simon TJ. Young adult female fragile $\mathrm{X}$ premutation carriers show age- and geneticallymodulated cognitive impairments. Brain Cognit. 2011a; 75:255-260. [PubMed: 21295394]

Goodrich-Hunsaker NJ, Wong LM, McLennan Y, Tassone F, Harvey D, Rivera SM, Simon TJ. Adult female Fragile X premutation carriers exhibit age- and CGG repeat length-related impairments on an attentionally based enumeration task. Front. Hum. Neurosci. 2011b; 5:63. [PubMed: 21808616]

Gosch A, Pankau R. Social-emotional and behavioral adjustment in children with Williams-Beuren syndrome. Am. J. Med. Genet. 1994; 53:335-339. [PubMed: 7864042]

Gosch A, Pankau R. Personality characteristics and behaviour problems in individuals of different ages with Williams syndrome. Dev. Med. Child Neurol. 1997; 39:527-533. [PubMed: 9295848]

Greaves N, Prince E, Evans DW, Charman T. Repetitive and ritualistic behaviour in children with Prader-Willi syndrome and children with autism. J. Intellect. Disabil. Res. 2006; 50:92-100. [PubMed: 16403198]

Green L, Fein D, Modahl C, Feinstein C, Waterhouse L, Morris M. Oxytocin and autistic disorder: alterations in peptide forms. Biol. Psychiatry. 2001; 50:609-613. [PubMed: 11690596]

Gross-Tsur V, Landau YE, Benarroch F, Wertman-Elad R, Shalev RS. Cognition, attention, and behavior in Prader-Willi syndrome. J. Child Neurol. 2001; 16:288-290. [PubMed: 11332464]

Guastella AJ, Mitchell PB, Dadds MR. Oxytocin increases gaze to the eye region of human faces. Biol. Psychiatry. 2008; 63:3-5. [PubMed: 17888410]

Guastella AJ, Einfeld SL, Gray KM, Rinehart NJ, Tonge BJ, Lambert TJ, Hickie IB. Intranasal oxytocin improves emotion recognition for youth with autism spectrum disorders. Biol. Psychiatry. 2010; 67:692-694. [PubMed: 19897177]

Gurkan CK, Hagerman RJ. Targeted treatments in autism and Fragile X syndrome. Res. Autism Spectr. Disord. 2012; 6:1311-1320. [PubMed: 23162607]

Hagerman R, Hoem G, Hagerman P. Fragile X and autism: Intertwined at the molecular level leading to targeted treatments. Mol. Autism. 2010; 1:12. [PubMed: 20858229]

Hagerman RJ, Berry-Kravis E, Kaufmann WE, Ono MY, Tartaglia N, Lachiewicz A, Kronk R, Delahunty C, Hessl D, Visootsak J, Picker J, Gane L, Tranfaglia M. Advances in the treatment of fragile X syndrome. Pediatrics. 2009; 123:378-390. [PubMed: 19117905]

Hall SS. Treatments for fragile X syndrome: a closer look at the data. Dev. Disabil. Res. Rev. 2009; 15:353-360. [PubMed: 20014373]

Hall SS, Lightbody AA, Huffman LC, Lazzeroni LC, Reiss AL. Physiological correlates of social avoidance behavior in children and adolescents with fragile x syndrome. J. Am. Acad. Child Adolesc. Psychiatry. 2009; 48:320-329. [PubMed: 19182690] 
Hall SS, Lightbody AA, McCarthy BE, Parker KJ, Reiss AL. Effects of intranasal oxytocin on social anxiety in males with fragile X syndrome. Psychoneuroendocrinology. 2012; 37:509-518. [PubMed: 21862226]

Hammock E, Veenstra-VanderWeele J, Yan Z, Kerr TM, Morris M, Anderson GM, Carter CS, Cook $\mathrm{EH}$, Jacob S. Examining autism spectrum disorders by biomarkers: example from the oxytocin and serotonin systems. J. Am. Acad. Child Adolesc. Psychiatry. 2012; 51:712-721. e1. [PubMed: 22721594]

Hampson DR, Adusei DC, Pacey LK. The neurochemical basis for the treatment of autism spectrum disorders and Fragile X syndrome. Biochem. Pharmacol. 2011; 81:1078-1086. [PubMed: 21333634]

Hatton DD, Sideris J, Skinner M, Mankowski J, Bailey DB Jr, Roberts J, Mirrett P. Autistic behavior in children with fragile X syndrome: prevalence, stability, and the impact of FMRP. Am. J. Med. Genet. A. 2006; 140A:1804-1813. [PubMed: 16700053]

Hessl D, Dyer-Friedman J, Glaser B, Wisbeck J, Barajas RG, Taylor A, Reiss AL. The influence of environmental and genetic factors on behavior problems and autistic symptoms in boys and girls with Fragile X syndrome. Pediatrics. 2001; 108:E88. [PubMed: 11694672]

Hinton VJ, Brown WT, Wisniewski K, Rudelli RD. Analysis of neocortex in three males with the Fragile X syndrome. Am. J. Med. Genet. 1991; 41:289-294. [PubMed: 1724112]

Hollander E, Novotny S, Hanratty M, Yaffe R, DeCaria CM, Aronowitz BR, Mosovich S. Oxytocin infusion reduces repetitive behaviors in adults with autistic and Asperger's disorders. Neuropsychopharmacology. 2003; 28:193-198. [PubMed: 12496956]

Hollander E, Bartz J, Chaplin W, Phillips A, Sumner J, Soorya L, Anagnostou E, Wasserman S. Oxytocin increases retention of social cognition in autism. Biol. Psychiatry. 2007; 61:498-503. [PubMed: 16904652]

Huber KM, Gallagher SM, Warren ST, Bear MF. Altered synaptic plasticity in a mouse model of fragile X mental retardation. Proc. Natl. Acad. Sci. USA. 2002; 99:7746-7750. [PubMed: 12032354]

Irwin SA, Galvez R, Greenough WT. Dendritic spine structural anomalies in Fragile-X mental retardation syndrome. Cereb. Cortex. 2000; 10:1038-1044. [PubMed: 11007554]

Irwin SA, Patel B, Idupulapati M, Harris JB, Crisostomo RA, Larsen BP, Kooy F, Willems PJ, Cras P, Kozlowski PB, Swain RA, Weiler IJ, Greenough WT. Abnormal dendritic spine characteristics in the temporal and visual cortices of patients with Fragile-X syndrome: a quantitative examination. Am. J. Med. Genet. 2001; 98:161-167. [PubMed: 11223852]

Irwin SA, Idupulapati M, Gilbert ME, Harris JB, Chakravarti AB, Rogers EJ, Crisostomo RA, Larsen BP, Mehta A, Alcantara CJ, Patel B, Swain RA, Weiler IJ, Oostra BA, Greenough WT. Dendritic spine and dendritic field characteristics of layer $\mathrm{V}$ pyramidal neurons in the visual cortex of Fragile-X knockout mice. Am. J. Med. Genet. 2002; 111:140-146. [PubMed: 12210340]

Ishak WW, Kahloon M, Fakhry H. Oxytocin role in enhancing well-being: a literature review. J. Affect. Disord. 2011; 130:1-9. [PubMed: 20584551]

Jacob S, Brune CW, Carter CS, Leventhal BL, Lord C, Cook EH Jr. Association of the oxytocin receptor gene (OXTR) in Caucasian children and adolescents with autism. Neurosci. Lett. 2007; 417:6-9. [PubMed: 17383819]

Jansen LM, Gispen-de Wied CC, Wiegant VM, Westenberg HG, Lahuis BE, van Engeland H. Autonomic and neuroendocrine responses to a psychosocial stressor in adults with autistic spectrum disorder. J. Autism Dev. Disord. 2006; 36:891-899. [PubMed: 16865550]

Jarvinen-Pasley A, Bellugi U, Reilly J, Mills DL, Galaburda A, Reiss AL, Korenberg JR. Defining the social phenotype in Williams syndrome: a model for linking gene, the brain, and behavior. Dev. Psychopathol. 2008; 20:1-35. [PubMed: 18211726]

Jarvinen-Pasley A, Adolphs R, Yam A, Hill KJ, Grichanik M, Reilly J, Mills D, Reiss AL, Korenberg JR, Bellugi U. Affiliative behavior in Williams syndrome: social perception and real-life social behavior. Neuropsychologia. 2010; 48:2110-2119. [PubMed: 20385151]

Jarvinen A, Korenberg JR, Bellugi U. The social phenotype of Williams syndrome. Curr. Opin. Neurobiol. 2013; 23:414-422. [PubMed: 23332975] 
Jaselskis CA, Cook EH Jr, Fletcher KE, Leventhal BL. Clonidine treatment of hyperactive and impulsive children with autistic disorder. J. Clin. Psychopharmacol. 1992; 12:322-327. [PubMed: 1479049]

Jemel B, Mottron L, Dawson M. Impaired face processing in autism: fact or artifact? J. Autism Dev. Disord. 2006; 36:91-106. [PubMed: 16477517]

Jin D, Liu HX, Hirai H, Torashima T, Nagai T, Lopatina O, Shnayder NA, Yamada K, Noda M, Seike T, Fujita K, Takasawa S, Yokoyama S, Koizumi K, Shiraishi Y, Tanaka S, Hashii M, Yoshihara T, Higashida K, Islam MS, Yamada N, Hayashi K, Noguchi N, Kato I, Okamoto H, Matsushima A, Salmina A, Munesue T, Shimizu N, Mochida S, Asano M, Higashida H. CD38 is critical for social behaviour by regulating oxytocin secretion. Nature. 2007; 446:41-45. [PubMed: 17287729]

Jorgensen H, Riis M, Knigge U, Kjaer A, Warberg J. Serotonin receptors involved in vasopressin and oxytocin secretion. J. Neuroendocrinol. 2003; 15:242-249. [PubMed: 12588512]

Kanner L. Autistic disturbances of affective contact. Nerv. Child. 1943; 2:217-250.

Kenkel WM, Paredes J, Yee JR, Pournajafi-Nazarloo H, Bales KL, Carter CS. Neuroendocrine and behavioural responses to exposure to an infant in male prairie voles. J. Neuroendocrinol. 2012; 24:874-886. [PubMed: 22356098]

Kirsch P. Oxytocin modulates neural circuitry for social cognition and fear in humans. J. Neurosci. 2005; 25:11489-11493. [PubMed: 16339042]

Kirsch P, Esslinger C, Chen Q, Mier D, Lis S, Siddhanti S, Gruppe H, Mattay VS, Gallhofer B, Meyer-Lindenberg A. Oxytocin modulates neural circuitry for social cognition and fear in humans. J. Neurosci. 2005; 25:11489-11493. [PubMed: 16339042]

Korenberg JR, Chen XN, Hirota H, Lai Z, Bellugi U, Burian D, Roe B, Matsuoka R. VI. Genome structure and cognitive map of Williams syndrome. J. Cogn. Neurosci. 2000; 12(Suppl. 1):S89S107.

Kosfeld M, Heinrichs M, Zak PJ, Fischbacher U, Fehr E. Oxytocin increases trust in humans. Nature. 2005; 435:673-676. [PubMed: 15931222]

Kuperman S, Beeghly JH, Burns TL, Tsai LY. Serotonin relationships of autistic probands and their first-degree relatives. J. Am. Acad. Child Psychiatry. 1985; 24:186-190. [PubMed: 3989161]

Kwon H, Menon V, Eliez S, Warsofsky IS, White CD, Dyer-Friedman J, Taylor AK, Glover GH, Reiss AL. Functional neuroanatomy of visuospatial working memory in fragile $\mathrm{X}$ syndrome: relation to behavioral and molecular measures. Am. J. Psychiatry. 2001; 158:1040-1051. [PubMed: 11431225]

Landgraf R, Wigger A. Born to be anxious: neuroendocrine and genetic correlates of trait anxiety in HAB rats. Stress. 2003; 6:111-119. [PubMed: 12775330]

Larson J, Jessen RE, Kim D, Fine AK, du Hoffmann J. Age-dependent and selective impairment of long-term potentiation in the anterior piriform cortex of mice lacking the fragile $\mathrm{X}$ mental retardation protein. J. Neurosci. 2005; 25:9460-9469. [PubMed: 16221856]

Lavi-Itzkovitz A, Tcherpakov M, Levy Z, Itzkovitz S, Muscatelli F, Fainzilber M. Functional consequences of necdin nucleocytoplasmic localization. PLoS One. 2012; 7:e33786. [PubMed: 22442722]

Leboyer M, Philippe A, Bouvard M, Guilloud-Bataille M, Bondoux D, Tabuteau F, Feingold J, Mouren-Simeoni MC, Launay JM. Whole blood serotonin and plasma beta-endorphin in autistic probands and their first-degree relatives. Biol. Psychiatry. 1999; 45:158-163. [PubMed: 9951562]

Leekam S, BaronCohen S, Perrett D, Milders M, Brown S. Eye-direction detection: a dissociation between geometric and joint attention skills in autism. Br. J. Dev. Psychol. 1997; 15:77-95.

Lerer E, Levi S, Israel S, Yaari M, Nemanov L, Mankuta D, Nurit Y, Ebstein RP. Low CD38 expression in lymphoblastoid cells and haplotypes are both associated with autism in a familybased study. Autism Res. 2010; 3:293-302. [PubMed: 21182206]

Leventhal BL, Cook EH Jr, Morford M, Ravitz A, Freedman DX. Relationships of whole blood serotonin and plasma norepinephrine within families. J. Autism Dev. Disord. 1990; 20:499-511. [PubMed: 2279970] 
Li J, Pelletier MR, Perez Velazquez JL, Carlen PL. Reduced cortical synaptic plasticity and GluR1 expression associated with fragile $\mathrm{X}$ mental retardation protein deficiency. Mol. Cell Neurosci. 2002; 19:138-151. [PubMed: 11860268]

Lim MM, Wang Z, Olazabal DE, Ren X, Terwilliger EF, Young LJ. Enhanced partner preference in a promiscuous species by manipulating the expression of a single gene. Nature. 2004; 429:754757. [PubMed: 15201909]

Lim MM, Bielsky IF, Young LJ. Neuropeptides and the social brain: potential rodent models of autism. Int. J. Dev. Neurosci. 2005; 23:235-243. [PubMed: 15749248]

Lord C, Rutter M, Le Couteur A. Autism diagnostic interview-revised: a revised version of a diagnostic interview for caregivers of individuals with possible pervasive developmental disorders. J. Autism Dev. Disord. 1994; 24:659-685. [PubMed: 7814313]

Lord C, Risi S, Lambrecht L, Cook EH Jr, Leventhal BL, DiLavore PC, Pickles A, Rutter M. The autism diagnostic observation schedule-generic: a standard measure of social and communication deficits associated with the spectrum of autism. J. Autism Dev. Disord. 2000; 30:205-223. [PubMed: 11055457]

Lowery MC, Morris CA, Ewart A, Brothman LJ, Zhu XL, Leonard CO, Carey JC, Keating M, Brothman AR. Strong correlation of elastin deletions, detected by FISH, with Williams syndrome: evaluation of 235 patients. Am. J. Hum. Genet. 1995; 57:49-53. [PubMed: 7611295]

Macdonald K, Macdonald TM. The peptide that binds: a systematic review of oxytocin and its prosocial effects in humans. Harv. Rev. Psychiatry. 2010; 18:1-21. [PubMed: 20047458]

Macdonald K, Feifel D. Helping oxytocin deliver: considerations in the development of oxytocinbased therapeutics for brain disorders. Front. Neurosci. 2013; 7:35. [PubMed: 23508240]

Maes B, Fryns JP, Van Walleghem M, Van den Berghe H. Cognitive functioning and information processing of adult mentally retarded men with fragile-X syndrome. Am. J. Med. Genet. 1994; 50:190-200. [PubMed: 8010351]

Martin A, State M, Anderson GM, Kaye WM, Hanchett JM, McConaha CW, North WG, Leckman JF. Cerebrospinal fluid levels of oxytocin in Prade-Willi syndrome: a preliminary report. Biol. Psychiatry. 1998; 44:1349-1352. [PubMed: 9861478]

McCracken JT, McGough J, Shah B, Cronin P, Hong D, Aman MG, Arnold LE, Lindsay R, Nash P, Hollway J, McDougle CJ, Posey D, Swiezy N, Kohn A, Scahill L, Martin A, Koenig K, Volkmar F, Carroll D, Lancor A, Tierney E, Ghuman J, Gonzalez NM, Grados M, Vitiello B, Ritz L, Davies M, Robinson J, McMahon D. Risperidone in children with autism and serious behavioral problems. N. Engl. J. Med. 2002; 347:314-321. [PubMed: 12151468]

McCullough ME, Churchland PS, Mendez AJ. Problems with measuring peripheral oxytocin: can the data on oxytocin and human behavior be trusted? Neurosci. Biobehav. Rev. 2013; 37:1485-1492. [PubMed: 23665533]

McLennan Y, Polussa J, Tassone F, Hagerman R. Fragile X syndrome. Curr. Genomics. 2011; 12:216-224. [PubMed: 22043169]

Mervis CB, Morris CA, Klein-Tasman BP, Bertrand J, Kwitny S, Appelbaum LG, Rice CE. Attentional characteristics of infants and toddlers with Williams syndrome during triadic interactions. Dev. Neuropsychol. 2003; 23:243-268. [PubMed: 12730027]

Miller M, Bales KL, Taylor SL, Yoon J, Hostetler CM, Carter CS, Solomon M. Oxytocin and vasopressin in children and adolescents with autism spectrum disorders: sex differences and associations with symptoms. Autism Res. 2013; 6:91-102. [PubMed: 23413037]

Mineur YS, Sluyter F, de Wit S, Oostra BA, Crusio WE. Behavioral and neuroanatomical characterization of the Fmr1 knockout mouse. Hippocampus. 2002; 12:39-46. [PubMed: 11918286]

Mineur YS, Huynh LX, Crusio WE. Social behavior deficits in the Fmr1 mutant mouse. Behav. Brain Res. 2006; 168:172-175. [PubMed: 16343653]

Modahl C, Green L, Fein D, Morris M, Waterhouse L, Feinstein C, Levin H. Plasma oxytocin levels in autistic children. Biol. Psychiatry. 1998; 43:270-277. [PubMed: 9513736]

Morris, CA. Williams Syndrome. Pagon, RA.; Adam, MP.; Bird, TD.; Dolan, CR.; Fong, CT.; Stephens, K., editors. Seattle (WA): GeneReviews; 1993. 
Morton JE, Bundey S, Webb TP, MacDonald F, Rindl PM, Bullock S. Fragile X syndrome is less common than previously estimated. J. Med. Genet. 1997; 34:1-5. [PubMed: 9032640]

Moy SS, Nadler JJ, Young NB, Perez A, Holloway LP, Barbaro RP, Barbaro JR, Wilson LM, Threadgill DW, Lauder JM, Magnuson TR, Crawley JN. Mouse behavioral tasks relevant to autism: phenotypes of 10 inbred strains. Behav. Brain Res. 2007; 176:4-20. [PubMed: 16971002]

Moy SS, Nadler JJ, Young NB, Nonneman RJ, Grossman AW, Murphy DL, D’Ercole AJ, Crawley JN, Magnuson TR, Lauder JM. Social approach in genetically engineered mouse lines relevant to autism. Genes Brain. Behav. 2009; 8:129-142. [PubMed: 19016890]

Munesue T, Yokoyama S, Nakamura K, Anitha A, Yamada K, Hayashi K, Asaka T, Liu HX, Jin D, Koizumi K, Islam MS, Huang JJ, Ma WJ, Kim UH, Kim SJ, Park K, Kim D, Kikuchi M, Ono Y, Nakatani H, Suda S, Miyachi T, Hirai H, Salmina A, Pichugina YA, Soumarokov AA, Takei N, Mori N, Tsujii M, Sugiyama T, Yagi K, Yamagishi M, Sasaki T, Yamasue H, Kato N, Hashimoto R, Taniike M, Hayashi Y, Hamada J, Suzuki S, Ooi A, Noda M, Kamiyama Y, Kido MA, Lopatina O, Hashii M, Amina S, Malavasi F, Huang EJ, Zhang J, Shimizu N, Yoshikawa T, Matsushima A, Minabe Y, Higashida H. Two genetic variants of CD38 in subjects with autism spectrum disorder and controls. Neurosci. Res. 2010; 67:181-191. [PubMed: 20435366]

Muscatelli F, Abrous DN, Massacrier A, Boccaccio I, Le Moal M, Cau P, Cremer H. Disruption of the mouse Necdin gene results in hypothalamic and behavioral alterations reminiscent of the human Prader-Willi syndrome. Hum. Mol. Genet. 2000; 9:3101-3110. [PubMed: 11115855]

Neumann ID, Landgraf R. Balance of brain oxytocin and vasopressin: implications for anxiety, depression, and social behaviors. Trends Neurosci. 2012; 35:649-659. [PubMed: 22974560]

Nielsen DM, Derber WJ, McClellan DA, Crnic LS. Alterations in the auditory startle response in Fmr1 targeted mutant mouse models of fragile X syndrome. Brain Res. 2002; 927:8-17. [PubMed: 11814427]

O'Donnell WT, Warren ST. A decade of molecular studies of Fragile X syndrome. Annu. Rev. Neurosci. 2002; 25:315-338. [PubMed: 12052912]

Owley T, Brune CW, Salt J, Walton L, Guter S, Ayuyao N, Gibbons RD, Leventhal BL, Cook EH. A pharmacogenetic study of escitalopram in autism spectrum disorders. Autism Res. 2010; 3:1-7. [PubMed: 20020537]

Paradee W, Melikian HE, Rasmussen DL, Kenneson A, Conn PJ, Warren ST. Fragile X mouse: strain effects of knockout phenotype and evidence suggesting deficient amygdala function. Neuroscience. 1999; 94:185-192. [PubMed: 10613508]

Paxinos, G.; Franklin, KBJ. The Mouse Brain in Stereotaxic Coordinates. Amsterdam; Boston: Elsevier Academic Press; 2004.

Peier AM, McIlwain KL, Kenneson A, Warren ST, Paylor R, Nelson DL. Over)correction of FMR1 deficiency with YAC transgenics: behavioral and physical features. Hum. Mol. Genet. 2000; 9:1145-1159. [PubMed: 10767339]

Petrovic P, Kalisch R, Singer T, Dolan RJ. Oxytocin attenuates affective evaluations of conditioned faces and amygdala activity. J. Neurosci. 2008; 28:6607-6615. [PubMed: 18579733]

Pietropaolo S, Guilleminot A, Martin B, D'Amato FR, Crusio WE. Genetic-background modulation of core and variable autistic-like symptoms in Fmr1 knock-out mice. PLoS One. 2011; 6:e17073. [PubMed: 21364941]

Plesa-Skwerer D, Faja S, Schofield C, Verbalis A, Tager-Flusberg H. Perceiving facial and vocal expressions of emotion in individuals with Williams syndrome. Am. J. Ment. Retard. 2006; 111:15-26. [PubMed: 16332153]

Pretorius PH, King MA, Pan TS, de Vries DJ, Glick SJ, Byrne CL. Reducing the influence of the partial volume effect on SPECT activity quantitation with 3D modelling of spatial resolution in iterative reconstruction. Phys. Med. Biol. 1998; 43:407-420. [PubMed: 9509535]

Proulx E, Young EJ, Osborne LR, Lambe EK. Enhanced prefrontal serotonin 5-HT(1A) currents in a mouse model of Williams-Beuren syndrome with low innate anxiety. J. Neurodev. Disord. 2010; 2:99-108. [PubMed: 20585377]

Reiss AL, Abrams MT, Greenlaw R, Freund L, Denckla MB. Neurodevelopmental effects of the FMR-1 full mutation in humans. Nat. Med. 1995; 1:159-167. [PubMed: 7585014] 
Riby D, Hancock PJ. Looking at movies and cartoons: eye-tracking evidence from Williams syndrome and autism. J. Intellect. Disabil. Res. 2009; 53:169-181. [PubMed: 19192099]

Rimmele U, Hediger K, Heinrichs M, Klaver P. Oxytocin makes a face in memory familiar. J. Neurosci. 2009; 29:38-42. [PubMed: 19129382]

Rodgers J, Riby DM, Janes E, Connolly B, McConachie H. Anxiety and repetitive behaviours in autism spectrum disorders and williams syndrome: a cross-syndrome comparison. J. Autism Dev. Disord. 2012; 42:175-180. [PubMed: 21424863]

Rudelli RD, Brown WT, Wisniewski K, Jenkins EC, Laure-Kamionowska M, Connell F, Wisniewski HM. Adult fragile X syndrome. Clinico-neuropathologic findings. Acta Neuropathol. 1985; 67:289-295. [PubMed: 4050344]

Ryan BC, Young NB, Crawley JN, Bodfish JW, Moy SS. Social deficits, stereotypy and early emergence of repetitive behavior in the C58/J inbred mouse strain. Behav. Brain Res. 2010; 208:178-188. [PubMed: 19941908]

Saitoh S, Buiting K, Cassidy SB, Conroy JM, Driscoll DJ, Gabriel JM, Gillessen-Kaesbach G, Glenn CC, Greenswag LR, Horsthemke B, Kondo I, Kuwajima K, Niikawa N, Rogan PK, Schwartz S, Seip J, Williams CA, Nicholls RD. Clinical spectrum and molecular diagnosis of Angelman and Prader-Willi syndrome patients with an imprinting mutation. Am. J. Med. Genet. 1997; 68:195206. [PubMed: 9028458]

Sakurai T, Dorr NP, Takahashi N, McInnes LA, Elder GA, Buxbaum JD. Haploinsufficiency of Gtf2i, a gene deleted in Williams Syndrome, leads to increases in social interactions. Autism Res. 2011; 4:28-39. [PubMed: 21328569]

Sala M, Braida D, Lentini D, Busnelli M, Bulgheroni E, Capurro V, Finardi A, Donzelli A, Pattini L, Rubino T, Parolaro D, Nishimori K, Parenti M, Chini B. Pharmacologic rescue of impaired cognitive flexibility, social deficits, increased aggression, and seizure susceptibility in oxytocin receptor null mice: a neurobehavioral model of autism. Biol. Psychiatry. 2011; 69:875-882. [PubMed: 21306704]

Sanders SJ, Ercan-Sencicek AG, Hus V, Luo R, Murtha MT, Moreno-De-Luca D, Chu SH, Moreau MP, Gupta AR, Thomson SA, Mason CE, Bilguvar K, Celestino-Soper PB, Choi M, Crawford EL, Davis L, Wright NR, Dhodapkar RM, DiCola M, DiLullo NM, Fernandez TV, FieldingSingh V, Fishman DO, Frahm S, Garagaloyan R, Goh GS, Kammela S, Klei L, Lowe JK, Lund SC, McGrew AD, Meyer KA, Moffat WJ, Murdoch JD, O'Roak BJ, Ober GT, Pottenger RS, Raubeson MJ, Song Y, Wang Q, Yaspan BL, Yu TW, Yurkiewicz IR, Beaudet AL, Cantor RM, Curland M, Grice DE, Gunel M, Lifton RP, Mane SM, Martin DM, Shaw CA, Sheldon M, Tischfield JA, Walsh CA, Morrow EM, Ledbetter DH, Fombonne E, Lord C, Martin CL, Brooks AI, Sutcliffe JS, Cook EH Jr, Geschwind D, Roeder K, Devlin B, State MW. Multiple recurrent de novo CNVs, including duplications of the 7q11.23 Williams syndrome region, are strongly associated with autism. Neuron. 2011; 70:863-885. [PubMed: 21658581]

Sauer C, Montag C, Worner C, Kirsch P, Reuter M. Effects of a common variant in the CD38 gene on social processing in an oxytocin challenge study: possible links to autism. Neuropsychopharmacology. 2012; 37:1474-1482. [PubMed: 22278094]

Sawchenko PE, Swanson LW. Localization, colocalization, and plasticity of corticotropin-releasing factor immunoreactivity in rat brain. Fed. Proc. 1985; 44:221-227. [PubMed: 2981743]

Schain RJ, Freedman DX. Studies on 5-hydroxyindole metabolism in autistic and other mentally retarded children. J. Pediatr. 1961; 58:315-320. [PubMed: 13747230]

Schapiro MB, Murphy DG, Hagerman RJ, Azari NP, Alexander GE, Miezejeski CM, Hinton VJ, Horwitz B, Haxby JV, Kumar A, et al. Adult fragile X syndrome: neuropsychology, brain anatomy, and metabolism. Am. J. Med. Genet. 1995; 60:480-493. [PubMed: 8825884]

Schneiderman I, Zagoory-Sharon O, Leckman JF, Feldman R. Oxytocin during the initial stages of romantic attachment: relations to couples' interactive reciprocity. Psychoneuroendocrinology. 2012; 37:1277-1285. [PubMed: 22281209]

Schradin C, Kenkel W, Krackow S, Carter CS. Staying put or leaving home: endocrine, neuroendocrine and behavioral consequences in male African striped mice. Horm. Behav. 2013; 63:136-143. [PubMed: 23079108]

Schubert C. The genomic basis of the Williams-Beuren syndrome. Cell Mol. Life Sci. 2009; 66:11781197. [PubMed: 19039520] 
Schultz RT. Developmental deficits in social perception in autism: the role of the amygdala and fusiform face area. Int. J. Dev. Neurosci. 2005; 23:125-141. [PubMed: 15749240]

Seltzer LJ, Ziegler TE, Pollak SD. Social vocalizations can release oxytocin in humans. Proc. Biol. Sci. 2010; 277:2661-2666. [PubMed: 20462908]

Shamay-Tsoory SG, Fischer M, Dvash J, Harari H, Perach-Bloom N, Levkovitz Y. Intranasal administration of oxytocin increases envy and schadenfreude (gloating). Biol. Psychiatry. 2009; 66:864-870. [PubMed: 19640508]

Silverman JL, Yang M, Turner SM, Katz AM, Bell DB, Koenig JI, Crawley JN. Low stress reactivity and neuroendocrine factors in the BTBR T+tf/J mouse model of autism. Neuroscience. 2010; 171:1197-1208. [PubMed: 20888890]

Silverman JL, Smith DG, Rizzo SJ, Karras MN, Turner SM, Tolu SS, Bryce DK, Smith DL, Fonseca K, Ring RH, Crawley JN. Negative allosteric modulation of the mGluR5 receptor reduces repetitive behaviors and rescues social deficits in mouse models of autism. Sci. Transl. Med. 2012; 4:131ra51.

Spencer CM, Alekseyenko O, Serysheva E, Yuva-Paylor LA, Paylor R. Altered anxiety-related and social behaviors in the Fmr1 knockout mouse model of fragile X syndrome. Genes, Brain Behav. 2005; 4:420-430. [PubMed: 16176388]

Swaab DF, Purba JS, Hofman MA. Alterations in the hypothalamic paraventricular nucleus and its oxytocin neurons (putative satiety cells) in Prader-Willi syndrome: a study of five cases. J. Clin. Endocrinol. Metab. 1995; 80:573-579. [PubMed: 7852523]

Szeto A, McCabe PM, Nation DA, Tabak BA, Rossetti MA, McCullough ME, Schneiderman N, Mendez AJ. Evaluation of enzyme immunoassay and radioimmunoassay methods for the measurement of plasma oxytocin. Psychosom. Med. 2011; 73:393-400. [PubMed: 21636661]

Takayanagi Y, Yoshida M, Bielsky IF, Ross HE, Kawamata M, Onaka T, Yanagisawa T, Kimura T, Matzuk MM, Young LJ, Nishimori K. Pervasive social deficits, but normal parturition, in oxytocin receptor-deficient mice. Proc. Natl. Acad. Sci. USA. 2005; 102:16096-16101. [PubMed: 16249339]

Tassone F, Hagerman RJ, Chamberlain WD, Hagerman PJ. Transcription of the FMR1 gene in individuals with fragile X syndrome. Am. J. Med. Genet. 2000a; 97:195-203. [PubMed: 11449488]

Tassone F, Hagerman RJ, Taylor AK, Gane LW, Godfrey TE, Hagerman PJ. Elevated levels of FMR1 mRNA in carrier males: a new mechanism of involvement in the fragile-X syndrome. Am. J. Hum. Genet. 2000b; 66:6-15. [PubMed: 10631132]

Tauber M, Mantoulan C, Copet P, Jauregui J, Demeer G, Diene G, Roge B, Laurier V, Ehlinger V, Arnaud C, Molinas C, Thuilleaux D. Oxytocin may be useful to increase trust in others and decrease disruptive behaviours in patients with Prader-Willi syndrome: a randomised placebocontrolled trial in 24 patients. Orphanet J. Rare Dis. 2011; 6:47. [PubMed: 21702900]

Teng BL, Nonneman RJ, Agster KL, Nikolova VD, Davis TT, Riddick NV, Baker LK, Pedersen CA, Jarstfer MB, Moy SS. Prosocial effects of oxytocin in two mouse models of autism spectrum disorders. Neuropharmacology. 2013; 72:187-196. [PubMed: 23643748]

The Dutch-Belgian Fragile-X Consortium. Fmr1 knockout mice: a model to study fragile X mental retardation. The Dutch-Belgian Fragile X Consortium. Cell. 1994; 78:23-33. [PubMed: 8033209]

Tsai TF, Jiang YH, Bressler J, Armstrong D, Beaudet AL. Paternal deletion from Snrpn to Ube3a in the mouse causes hypotonia, growth retardation and partial lethality and provides evidence for a gene contributing to Prader-Willi syndrome. Hum. Mol. Genet. 1999; 8:1357-1364. [PubMed: 10400982]

Turner G, Webb T, Wake S, Robinson H. Prevalence of fragile X syndrome. Am. J. Med. Genet. 1996; 64:196-197. [PubMed: 8826475]

Vorstman JA, Staal WG, van Daalen E, van Engeland H, Hochstenbach PF, Franke L. Identification of novel autism candidate regions through analysis of reported cytogenetic abnormalities associated with autism. Mol. Psychiatry. 2006; 11(1):18-28.

Wang LW, Berry-Kravis E, Hagerman RJ. Fragile X: leading the way for targeted treatments in autism. Neurotherapeutics. 2010; 7:264-274. [PubMed: 20643379] 
Waterhouse L, Fein D, Modahl C. Neurofunctional mechanisms in autism. Psychol. Rev. 1996; 103:457-489. [PubMed: 8759044]

Webb S. Drugmakers dance with autism. Nat. Biotechnol. 2010; 28:772-774. [PubMed: 20697394]

Weiler IJ, Irwin SA, Klintsova AY, Spencer CM, Brazelton AD, Miyashiro K, Comery TA, Patel B, Eberwine J, Greenough WT. Fragile X mental retardation protein is translated near synapses in response to neurotransmitter activation. Proc. Natl. Acad. Sci. USA. 1997; 94:5395-5400. [PubMed: 9144248]

Weiler IJ, Spangler CC, Klintsova AY, Grossman AW, Kim SH, Bertaina-Anglade V, Khaliq H, de Vries FE, Lambers FA, Hatia F, Base CK, Greenough WT. Fragile X mental retardation protein is necessary for neurotransmitter-activated protein translation at synapses. Proc. Natl. Acad. Sci. USA. 2004; 101:17504-17509. [PubMed: 15548614]

Whitman BY, Accardo P. Emotional symptoms in Prader- Willi syndrome adolescents. Am. J. Med. Genet. 1987; 28:897-905. [PubMed: 3688028]

Whittington J, Holland T. Recognition of emotion in facial expression by people with Prader-Willi syndrome. J. Intellect. Disabil. Res. 2011; 55:75-84. [PubMed: 21121995]

Williams JC, Barratt-Boyes BG, Lowe JB. Supravalvular aortic stenosis. Circulation. 1961; 24:13111318. [PubMed: 14007182]

Wilson BM, Cox CL. Absence of metabotropic glutamate receptor-mediated plasticity in the neocortex of fragile X mice. Proc. Natl. Acad. Sci. USA. 2007; 104:2454-2459. [PubMed: 17287348]

Winslow JT, Insel TR. Neuroendocrine basis of social recognition. Curr. Opin. Neurobiol. 2004; 14:248-253. [PubMed: 15082332]

Wismer Fries AB, Ziegler TE, Kurian JR, Jacoris S, Pollak SD. Early experience in humans is associated with changes in neuropeptides critical for regulating social behavior. Proc. Natl. Acad. Sci. USA. 2005; 102:17237-17240. [PubMed: 16303870]

Wisniewski KE, Segan SM, Miezejeski CM, Sersen EA, Rudelli RD. The Fra(X) syndrome: neurological, electrophysiological, and neuropathological abnormalities. Am. J. Med. Genet. 1991; 38:476-480. [PubMed: 2018089]

Witt DM, Insel TR. Central oxytocin antagonism decreases female reproductive behavior. Ann. N. Y. Acad. Sci. 1992; 652:445-447. [PubMed: 1320836]

Witt DM, Winslow JT, Insel TR. Enhanced social interactions in rats following chronic, centrally infused oxytocin. Pharmacol. Biochem. Behav. 1992; 43:855-861. [PubMed: 1448480]

Wohrle D, Kotzot D, Hirst MC, Manca A, Korn B, Schmidt A, Barbi G, Rott HD, Poustka A, Davies $\mathrm{KE}$, et al. A microdeletion of less than $250 \mathrm{~kb}$, including the proximal part of the FMR-I gene and the Fragile-X site, in a male with the clinical phenotype of fragile-X syndrome. Am. J. Hum. Genet. 1992; 51:299-306. [PubMed: 1642231]

Wu S, Jia M, Ruan Y, Liu J, Guo Y, Shuang M, Gong X, Zhang Y, Yang X, Zhang D. Positive association of the oxytocin receptor gene (OXTR) with autism in the Chinese Han population. Biol. Psychiatry. 2005; 58:74-77. [PubMed: 15992526]

Xu XJ, Shou XJ, Li J, Jia MX, Zhang JS, Guo Y, Wei QY, Zhang XT, Han SP, Zhang R, Han JS. Mothers of autistic children: lower plasma levels of oxytocin and arg-vasopressin and a higher level of testosterone. PLoS One. 2013; 8:e74849. [PubMed: 24086383]

Yamamoto Y, Cushing BS, Kramer KM, Epperson PD, Hoffman GE, Carter CS. Neonatal manipulations of oxytocin alter expression of oxytocin and vasopressin immunoreactive cells in the paraventricular nucleus of the hypothalamus in a gender-specific manner. Neuroscience. 2004; 125:947-955. [PubMed: 15120854]

Yan QJ, Asafo-Adjei PK, Arnold HM, Brown RE, Bauchwitz RP. A phenotypic and molecular characterization of the fmr1-tm1Cgr fragile X mouse. Genes Brain Behav. 2004; 3:337-359. [PubMed: 15544577]

Yoshida M, Takayanagi Y, Inoue K, Kimura T, Young LJ, Onaka T, Nishimori K. Evidence that oxytocin exerts anxiolytic effects via oxytocin receptor expressed in serotonergic neurons in mice. J. Neurosci. 2009; 29:2259-2271. [PubMed: 19228979]

Young LJ, Flanagan-Cato LM. Editorial comment: oxytocin, vasopressin and social behavior. Horm. Behav. 2012; 61:227-229. [PubMed: 22443808] 
Yrigollen CM, Han SS, Kochetkova A, Babitz T, Chang JT, Volkmar FR, Leckman JF, Grigorenko EL. Genes controlling affiliative behavior as candidate genes for autism. Biol. Psychiatry. 2008; 63:911-916. [PubMed: 18207134]

Zhao MG, Toyoda H, Ko SW, Ding HK, Wu LJ, Zhuo M. Deficits in trace fear memory and long-term potentiation in a mouse model for fragile X syndrome. J. Neurosci. 2005; 25:7385-7392. [PubMed: 16093389]

Zhong S, Monakhov M, Mok HP, Tong T, Lai PS, Chew SH, Ebstein RP. U-shaped relation between plasma oxytocin levels and behavior in the trust game. PLoS One. 2012; 7:e51095. [PubMed: 23227239] 
Wild Type
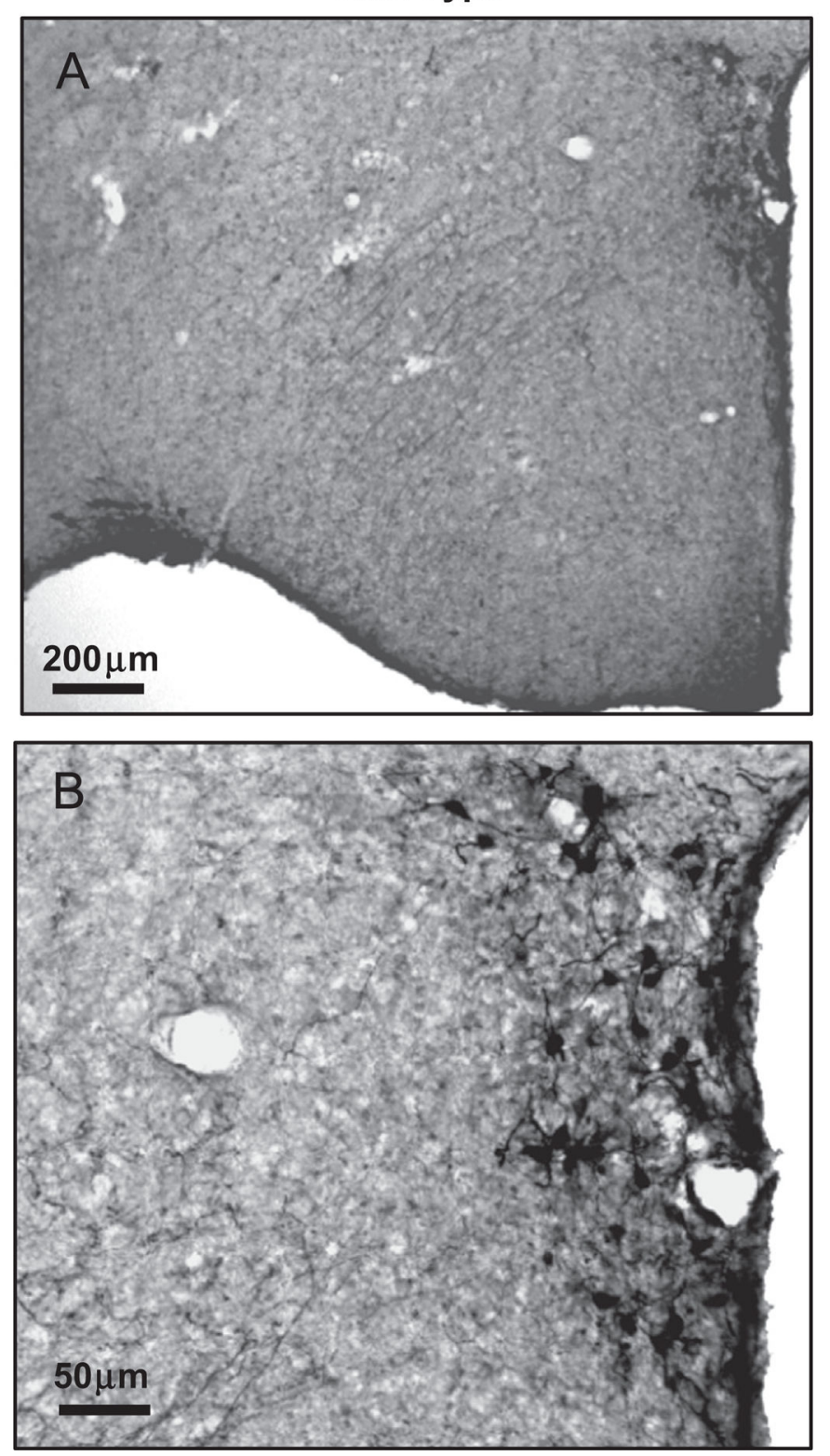

Knockout
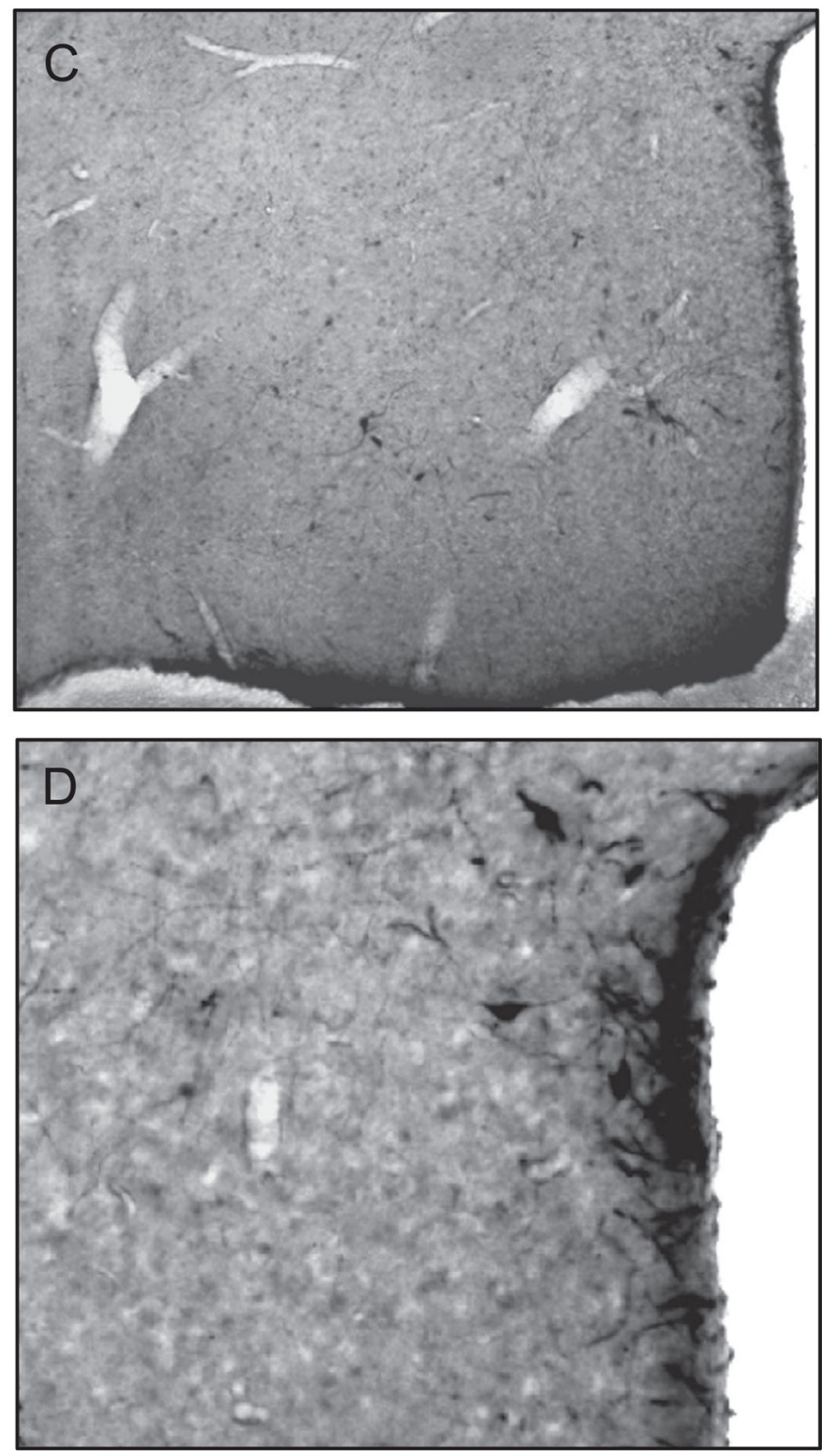

Fig. 1.

Expression of OT in the paraventricular nucleus (PVN), as measured by ICC, is reduced in Fmrl KO mice as compared to the wild-type (WT). Methods: The animal model was generated with WT and Fmrl KO mice from a colony founded with stock obtained from the Jackson Laboratory (Bar Harbor, ME, USA) that was backcrossed onto a B6 background > 10 generations. Mice were genotyped using primers described previously (the DutchBelgian Fragile-X Consortium, 1994). Cells were stained using the immunocytochemical (ICC) staining procedures, following protocols described in early work on OT and AVP in voles (Yamamoto et al., 2004). All sections were double-stained for NeuN (a marker that stains cell nuclei only in neurons), which allowed precise localization of cytoarchitectonic boundaries. Stained sections were mounted on subbed slides and examined with OT and 
AVP antibodies (OT antibodies were generously provided by M. Morris and AVP antibodies were obtained from MP Biomedical \#647171, formerly ICN; Solon, OH, USA). Slices of tissue for each animal were categorized as described in (Paxinos and Franklin, 2004) and carefully matched across subjects to allow comparable sections. Imaged slides were captured at $10 \times$, then coded and scored by an experimentally blind scorer using Image $\mathbf{J}$ (NIH, Bethesda, MD) software. OT and AVP stained cells in the PVN of the hypothalamus regions were stained separately for OT and AVP ( $N=6-7$ mice per group). Boxed sampling areas were: $125 \times 125 \mu \mathrm{m}^{2}$ (PVN total staining density), $250 \times 375 \mu \mathrm{m}^{2}$ (PVN fibers), 93.75 $\times 93.75 \mu \mathrm{m}^{2}$ for cell counts bilaterally in both the PVN and SON. 

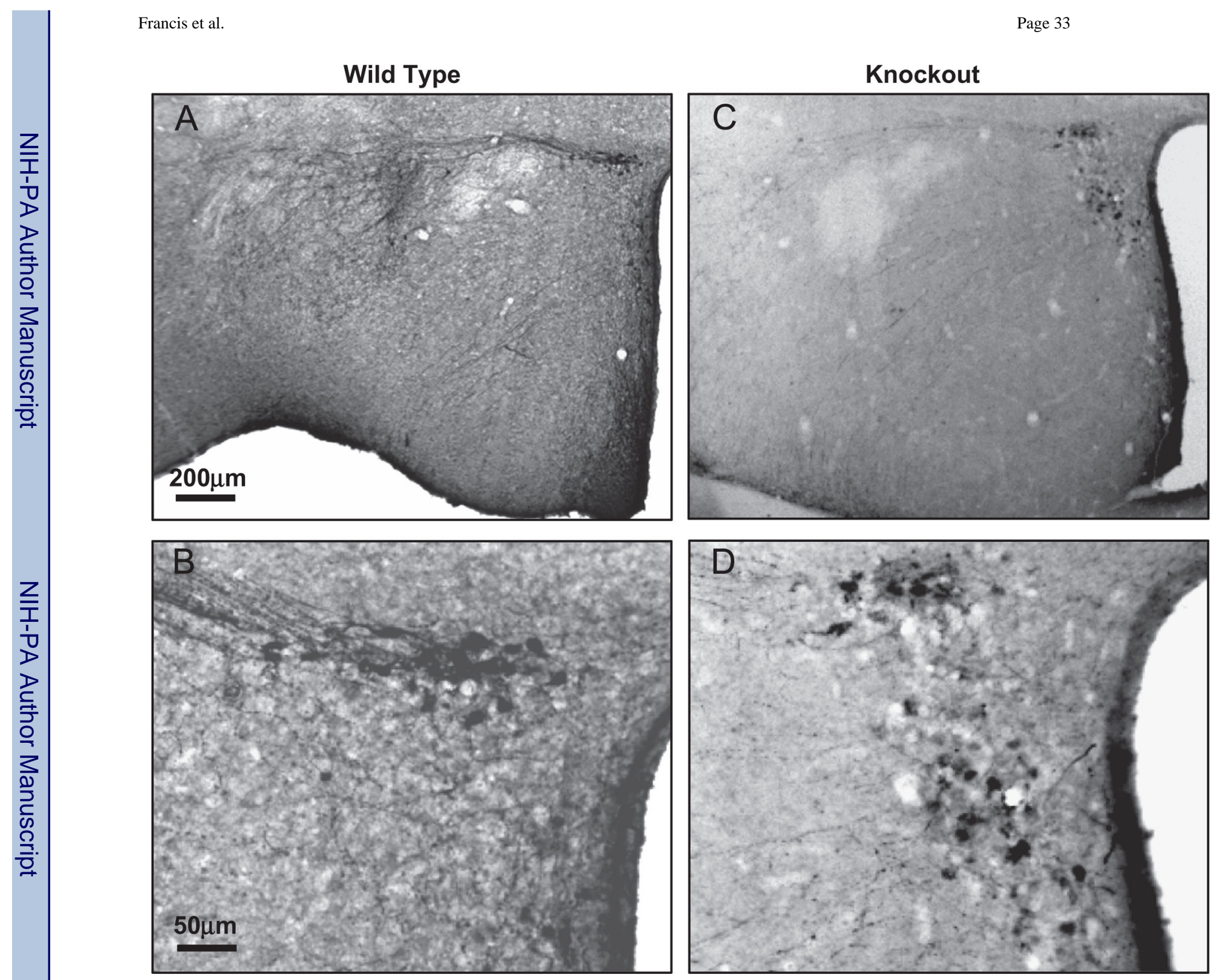

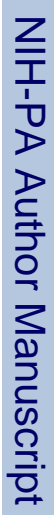

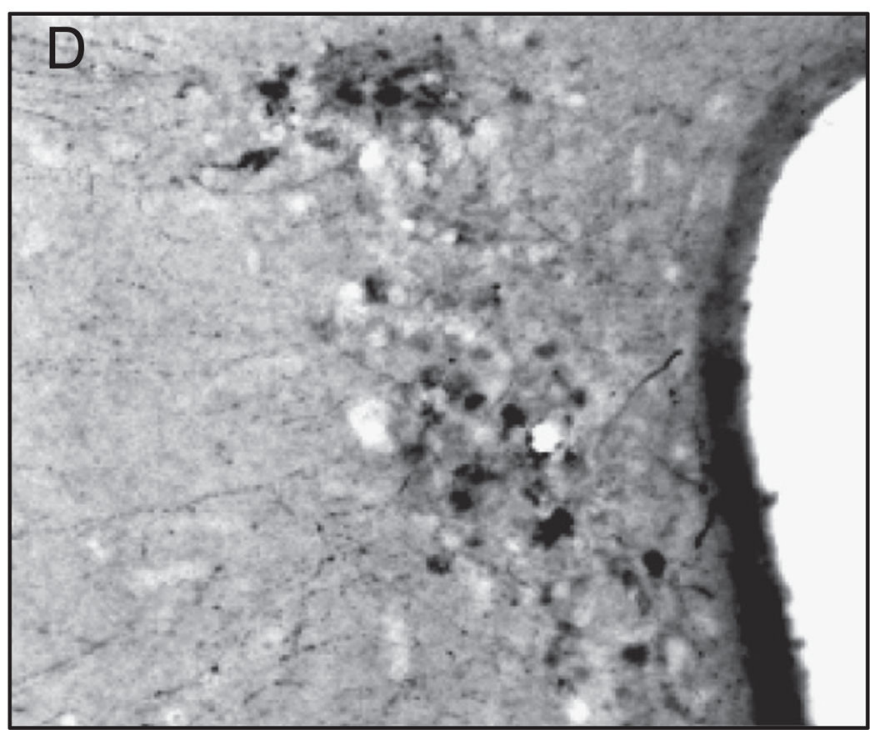

Fig. 2.

Expression of AVP in the paraventricular nucleus (PVN). In Fmrl KO mice, as compared to the wild-type (WT) AVP expression is reduced as measured by ICC. 

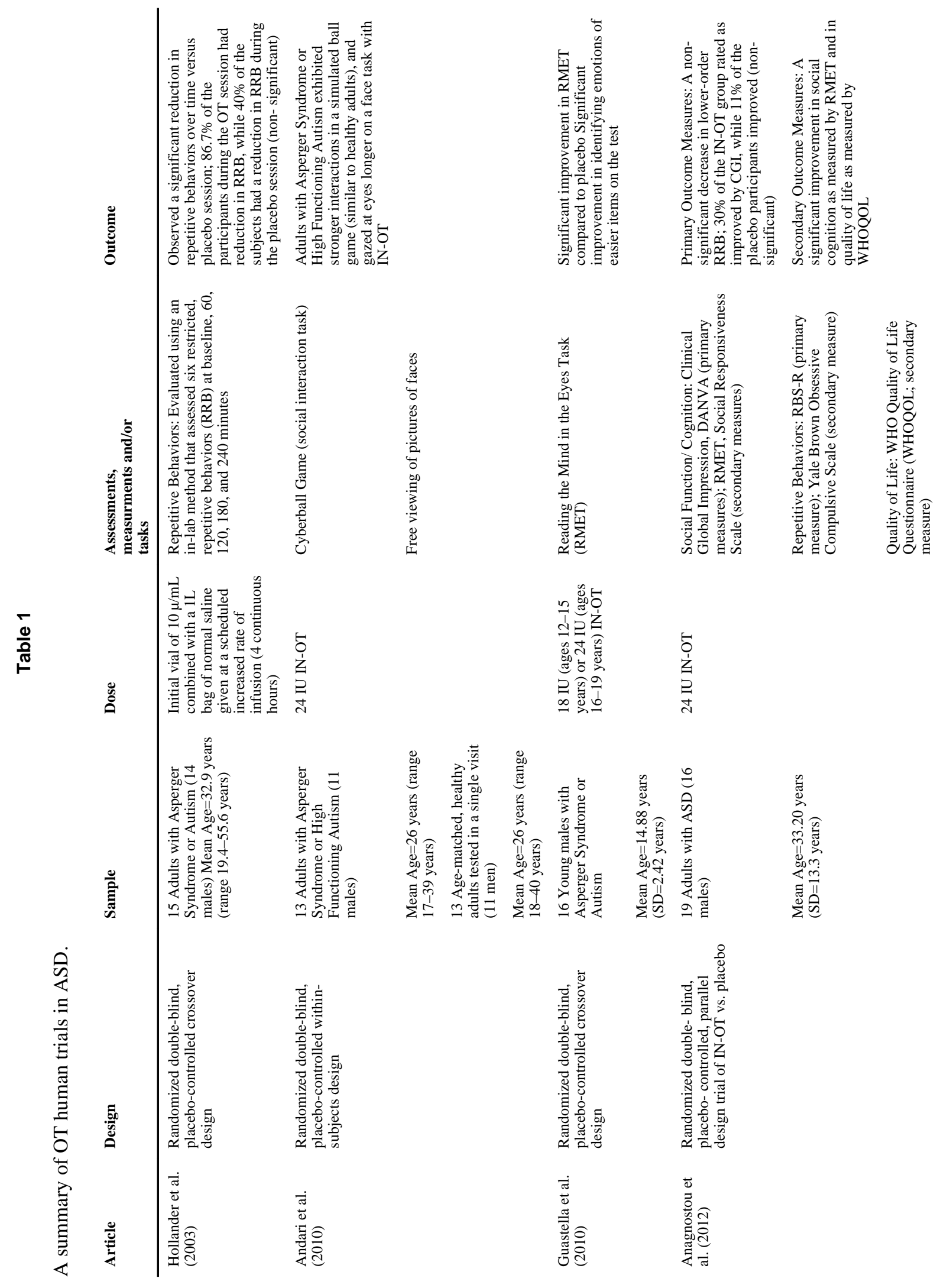


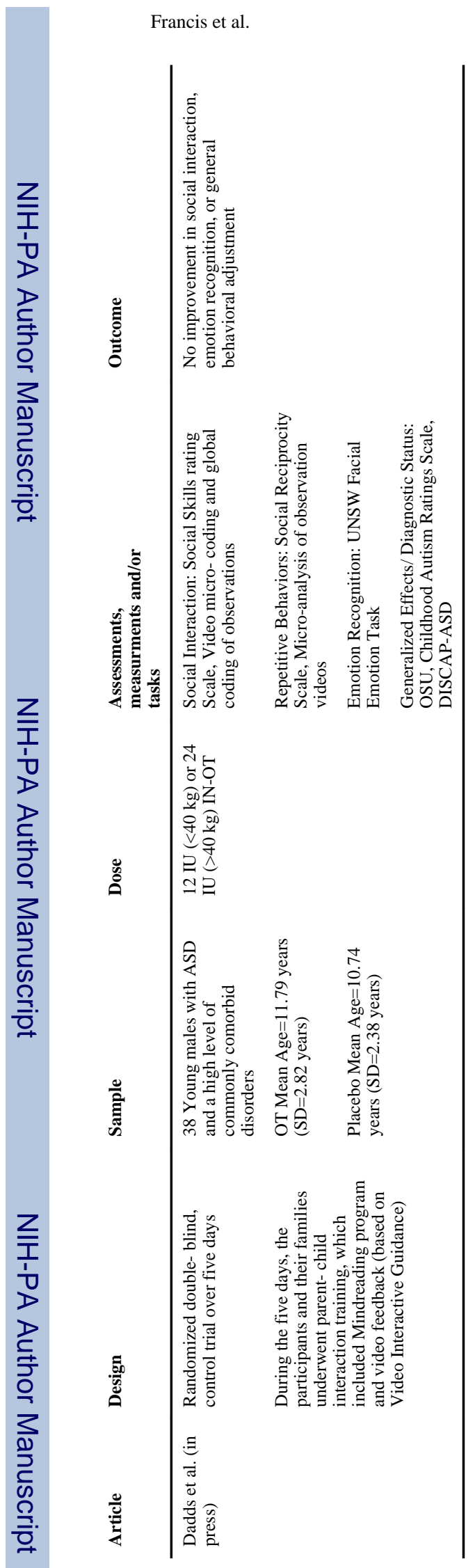

Page 35 


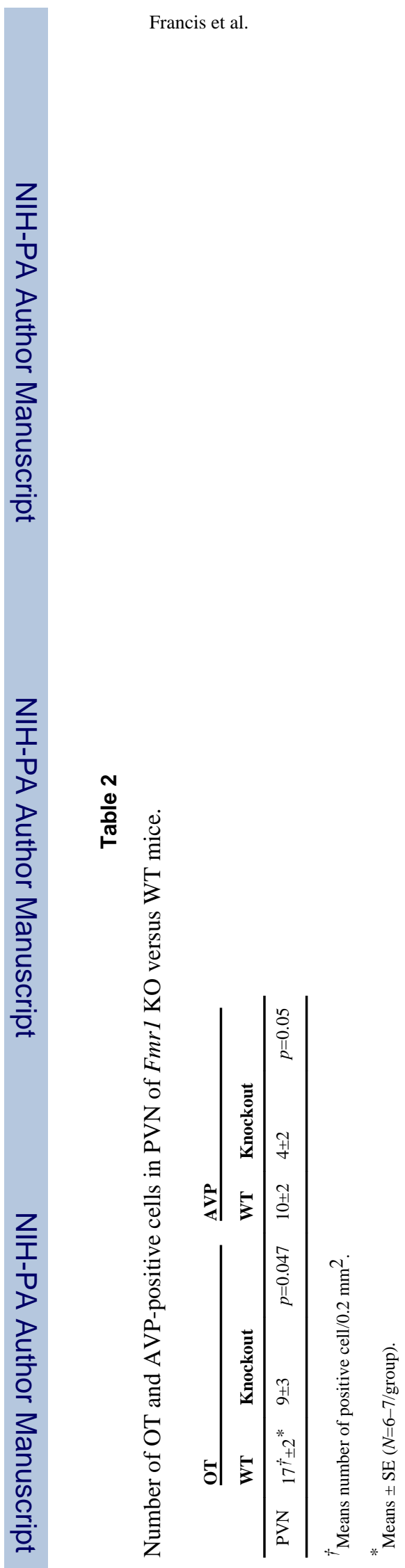

Brain Res. Author manuscript; available in PMC 2015 January 25. 


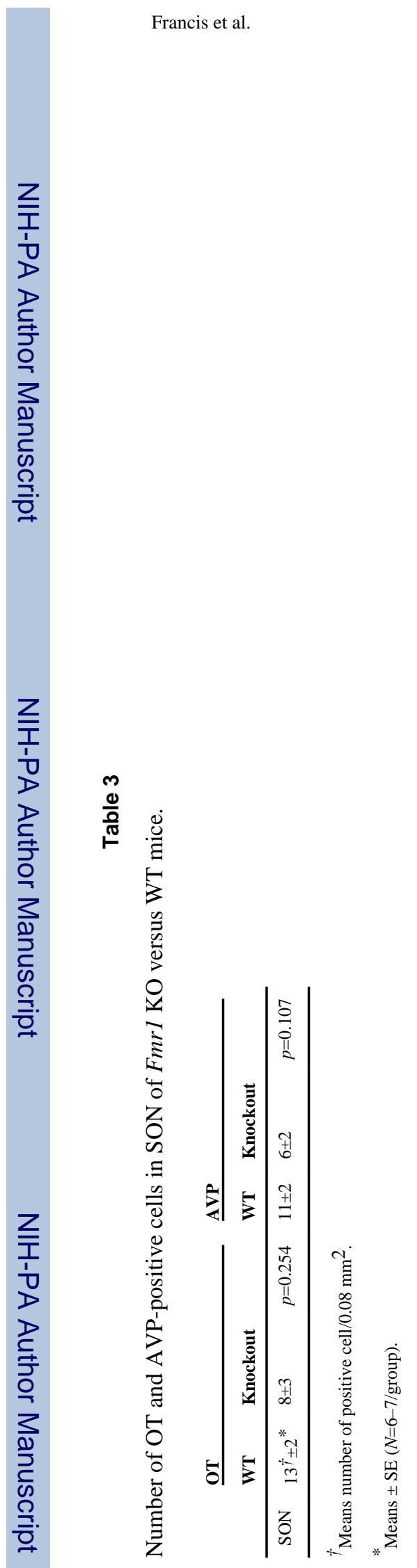

Brain Res. Author manuscript; available in PMC 2015 January 25. 


\section{Table 4}

\section{A Summary of OT Affects on NDD.}

\begin{tabular}{|c|c|c|}
\hline Disorder & Neuropeptide system affected & References \\
\hline Autism spectrum & Atypical ( $\downarrow \uparrow$ observed) levels of OT in blood (human) & Modahl et al. (1998) \\
\hline \multirow[t]{2}{*}{ disorders } & $\begin{array}{l}\text { IN-OT } \uparrow \text { social task performance and } \downarrow \text { repetitive behaviors } \\
\text { (human) }\end{array}$ & Andari et al. (2010) and Hollander et al. (2003) \\
\hline & To be studied: human neuropathology and animal models & For a more extensive list of human trials see Table 1 \\
\hline \multirow[t]{4}{*}{ Prader-Willi syndrome } & $\downarrow$ OT producing cells in the PVN (human) & Swaab et al. (1995) \\
\hline & $\downarrow$ Level of OT in CSF (human) & Martin et al. (1998) \\
\hline & IN-OT $\uparrow$ trust and $\downarrow$ disruptive behaviors (human) & Tauber et al. (2011) \\
\hline & $\downarrow$ Hypothalamic OT in Magedl deletion model (animal) & Dombret et al. (2012) \\
\hline \multirow[t]{2}{*}{ Williams syndrome } & $\uparrow$ OT levels (human) & Dai et al. (2012) \\
\hline & To be studied: human neuropathology and animal models & \\
\hline \multirow[t]{4}{*}{ Fragile X syndrome } & $\downarrow \mathrm{OT}+$ and AVP+ cells in the PVN (Fmrl KO mice) & See Tables 2 and 3, and Figs. 1 and 2 \\
\hline & IN-OT $\uparrow$ eye gaze frequency (human) & Hall et al. (2009) and Hall et al. (2012) \\
\hline & IN-OT $\downarrow$ salivary cortisol (human) & Hall et al. (2012) \\
\hline & To be studied: human neuropathology & \\
\hline
\end{tabular}

